\title{
Effect of platelet-rich fibrin on cell proliferation, migration, differentiation, inflammation, and osteoclastogenesis: a systematic review of in vitro studies
}

\author{
Franz-Josef Strauss $^{1,2}$ (D) Jila Nasirzade ${ }^{1} \cdot$ Zahra Kargarpoor $^{1} \cdot$ Alexandra Stähli $^{1,3} \cdot$ Reinhard Gruber $^{1,3,4}$ (D)
}

Received: 6 August 2019 / Accepted: 13 November 2019 / Published online: 26 December 2019

(C) The Author(s) 2019

\begin{abstract}
Objective To systematically assess the effects of platelet-rich fibrin (PRF) on in vitro cellular behavior.

Methods A systematic electronic search using MEDLINE database was performed. In vitro studies using PRF were considered and articles published up to June 31, 2018 were screened. Eligible studies were selected based on the use of human PRF.

Results In total, 1746 titles were identified with the search terms, from these 37 met the inclusion criteria and were chosen for data extraction. In addition, 16 new studies, mainly published in 2019, were also included in the analysis resulting in 53 studies. No meta-analysis could be performed due to the heterogeneity of study designs. Included studies show that PRF enhances proliferation, migration, adhesion, and osteogenic differentiation on a variety of cell types along with cell signaling activation. Furthermore, PRF reduces inflammation, suppresses osteoclastogenesis, and increases the expression of various growth factors in mesenchymal cells.

Summary and conclusions Despite some notable differences of the studies, the overall findings suggest a positive effect of PRF on cell proliferation, migration, adhesion, differentiation, and inflammation pointing towards a therapeutic potential in regenerative dentistry.

Clinical relevance PRF serves as a reservoir of bioactive molecules to support wound healing and bone regeneration. Although the cellular mechanisms by which PRF supports the clinical outcomes remain unclear, in vitro research provides possible explanations. This systematic review aims to provide an update of the existing research on how PRF affects basic physiological processes in vitro. The overall findings suggest that PRF induces cell proliferation, migration, adhesion, and differentiation along with possessing anti-inflammatory properties further supporting its therapeutic potential in wound healing and bone regeneration.
\end{abstract}

Keywords Platelet-rich fibrin - In vitro · Growth factor - Cell proliferation · Cell migration - Cell differentiation . Anti-inflammatory agents $\cdot$ Osteoclastogenesis

Reinhard Gruber

reinhard.gruber@meduniwien.ac.at

1 Department of Oral Biology, School of Dentistry, Medical University of Vienna, Sensengasse 2a, 1090 Vienna, Austria

2 Department of Conservative Dentistry, School of Dentistry, Universidad de Chile, Av. Sergio Livingstone, 943 Santiago, Chile

3 Department of Periodontology, School of Dental Medicine, University of Bern, Freiburgstrasse 7, 3010 Bern, Switzerland

4 Austrian Cluster for Tissue Regeneration, Donaueschingenstrasse 13, 1200, Vienna, Austria

\section{Introduction}

Platelet-rich fibrin (PRF) is becoming an attractive and widely-used approach in regenerative dentistry. PRF is a platelet-rich plasma that undergoes natural coagulation after being separated from the red thrombus by centrifugation [1]. The evolution of PRF started with the introduction of L-PRF based on a high-speed protocol $(\sim 700 \mathrm{~g}$ for $12 \mathrm{~min}$ ) [1]. Later on, A-PRF ( $\sim 200 \mathrm{~g}$ for $8 \mathrm{~min})$ and injectable PRF ( $\sim 60 \mathrm{~g}$ for $3 \mathrm{~min})$ with lower $\mathrm{g}$-forces and centrifugation times were introduced with the overall aim to increase the number of platelets and leucocytes [2]. For this aim, the use of centrifuges with swing-out rotors has also been recommended [2]. Obviously PRF is an umbrella term that comprises various preparations and protocols, therefore a 
standardization of relative centrifugal forces (RCF) [3] has been suggested. Nonetheless, most of the clinical data derive from the classical L-PRF protocol [1].

Recent systematic reviews dealt with the clinical application of PRF in periodontal defects, periodontal plastic surgery [4], sinus floor elevation, alveolar ridge preservation, or implant therapy [5]. For example, PRF preserves the alveolar ridge after tooth extraction [6], enhances osseointegration in the early phase $[7,8]$ and can increase the width of keratinized mucosa around implants [9]. Even though emerging evidence indicates that local application of PRF can support the outcomes of the above-mentioned clinical indications, the underlying cellular mechanisms remain unclear. Based on the assumption that PRF supports the conserved cellular mechanisms of wound healing and bone regeneration, it can, therefore, be assumed that PRF drives the cellular responses also under in vitro conditions.

In vitro bioassays can confirm the impact of PRF on standard cellular responses such as proliferation, migration, and differentiation, all of which may predict a possible clinical efficacy. However, care should be taken when interpreting the observations, as the early hematoma that usually forms in defect sites is not represented in the in vitro assays [10].
Readers of this review should also be aware that some of the observations reported for PRF have already been shown for plasma-free leucocyte-depleted activated platelets [11-13] based on the compelling in vitro evidence gained from platelet-rich plasma [14, 15].

The cellular responses to PRF were summarized in a systematic review integrating seven in vitro studies [16]. However, given the increasing number of in vitro studies, not limited to dentistry, a revised view on today's in vitro research on PRF seems justified. This systematic review aims to provide an update of the existing research on how PRF affects basic physiological processes in vitro.

\section{Material and methods}

\section{Protocol development and eligibility criteria}

A protocol including all aspects of a systematic review methodology was developed prior to starting the review. This included definition of the focused question, a defined search strategy, study inclusion criteria, determination of outcome

Fig. 1 PRISMA Flow Diagram
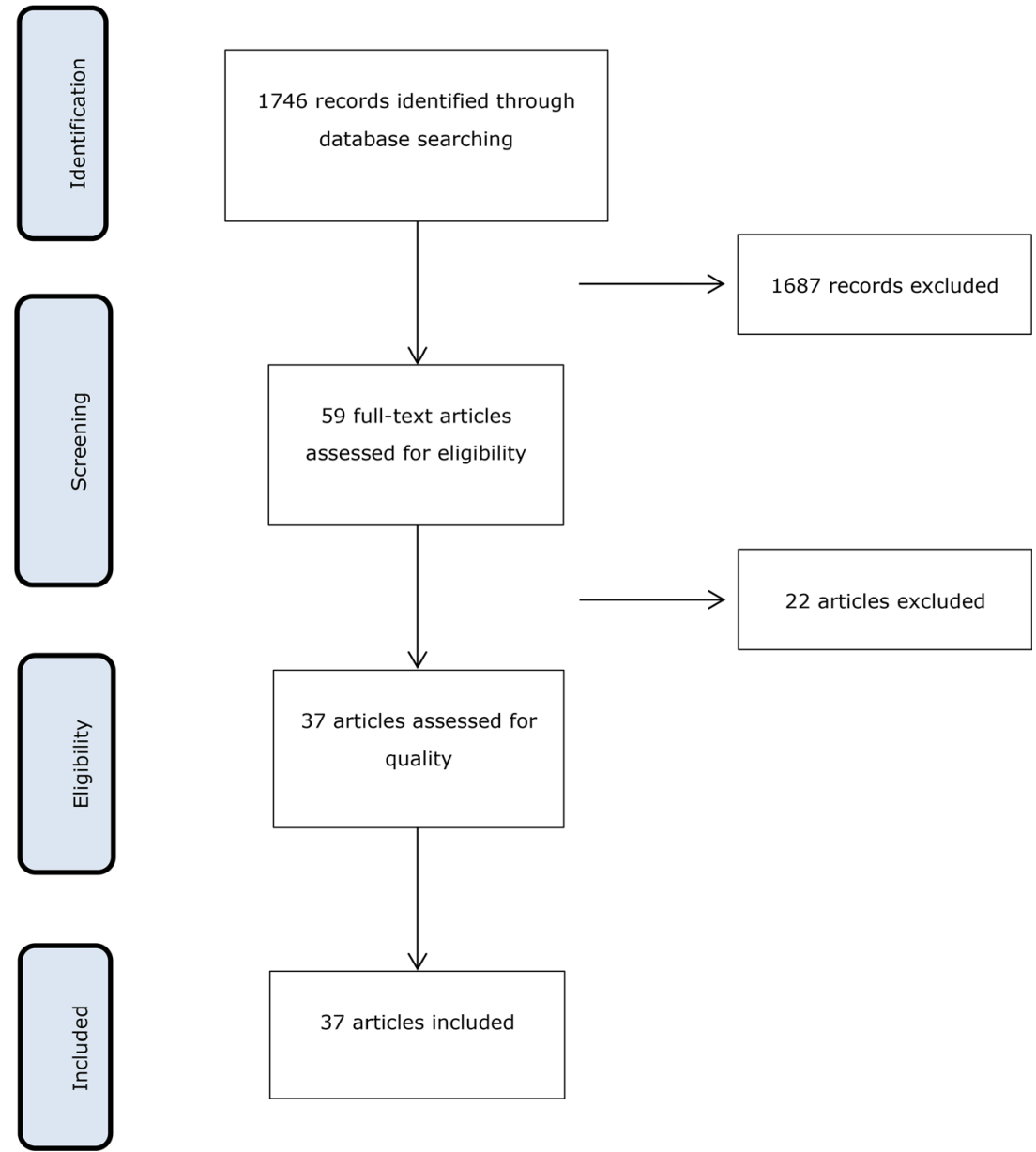
measures, screening methods, data extraction, and analysis and data synthesis.

\section{Defining the focused question}

The following focused question was defined: "what is the effect of PRF on cell behavior in in vitro studies?"

\section{Search strategy}

An electronic search using MEDLINE database was performed. Articles published up to June 30, 2018 were considered. No language or time restrictions were applied in the search. However, only studies written in English were included for selection.

\section{Search terms}

The electronic search strategy included terms related to the intervention and used the following combination of key words and MeSH terms: leukocyte platelet-rich fibrin" OR "pure platelet-rich fibrin" OR "LPRF” OR "L-PRF” OR “advanced platelet-rich fibrin” OR “APRF” OR “A-PRF” OR “L-PRF Gel" OR "leukocytes" OR "platelets" OR "blood platelets" OR "platelet" AND "in vitro techniques" OR "cytokines" OR "intercellular signaling peptides and proteins" OR "intercellular" OR intercellular signaling peptides and proteins" OR "growth factors" OR "transforming growth factor beta" OR "bone marrow" OR "stem cells" OR "macrophages" OR "osteoclasts” OR "inflammation" OR "Cell Physiological Phenomena" OR "Cell Plasticity" OR "cell differentiation" OR “osseointegration” OR "Dental Implants."

\section{Criteria for study selection and inclusion}

Only in vitro studies evaluating the effect of PRF were considered.

\section{Exclusion criteria}

In vitro studies using other kinds of platelet concentrates such as PRGF or PRP or any other platelet concentrate that required the addition of anticoagulant. Pre-clinical and in vitro studies that did not use human blood.

\section{Screening and selection of studies}

Publication records and titles identified by the electronic search were independently screened by two reviewers ( $\mathrm{JN}$ and $\mathrm{ZK}$ ) based on the inclusion criteria. Discrepancies were solved by discussion among authors (RG and FJS). Cohen's Kappa-coefficient was used as a measure of agreement between the readers. Thereafter, full texts of the selected abstracts were obtained. The two reviewers independently performed the screening process, i.e., from the MeSH term search up to the full-text examination. Then, articles that met the inclusion criteria were processed for data extraction.

\section{Data extraction and analysis}

The inclusion criteria were applied for data extraction. The studies were classified according to study design and type of methods applied. Then, outcomes were compiled in tables. All extracted data were double-checked, and any questions that came up during the screening and the data extraction were discussed within the authors to aim for consensus.

\section{Results}

\section{Selection of studies}

In the original search 1746 potential references were identified in Medline which 59 were eligible after title and abstract screening (inter-reviewer agreement $\kappa=0.952$ ). Of the 59 full-text articles, 22 did not meet the inclusion criteria and were excluded (Fig. 1) obtaining 37 studies for data extraction (Table 1). During the submissionprocess of the present review, 16 new studies meeting the inclusion criteria were published and therefore included for data extraction (Table 2).

\section{Proliferation}

PRF increased proliferation of mesenchymal cells, for example from bone of different origin [19, 24-26, 28, 45, 50, 66, ], bone marrow [32, 39], periosteum [27], adipose tissue [37, 47, 68], and skin $[65,48]$. Also, fibroblasts from gingiva [38, 44], periodontal ligament [18, 52, 59], papilla [30], and dental pulp responded to PRF with increased proliferation [29, 31, 43, 54]. These observations were reproduced in embryonic kidney fibroblasts and in various cell lines such as HEK293, MG-63 osteosarcoma cells, human oral keratinocytes, SIRC, and 3T3 cells [18]. Mesenchymal cells, endothelial cells [23, 42, 55, 63], epithelial cells [22], and macrophages [69] also responded to PRF with increasing proliferation. In contrast, PRF failed to induce proliferation of L929 fibroblasts [53] and human mesenchymal stem cells on collagen scaffolds [17]. In general, PRF maintained cell viability [33, 63-66, ] without inducing apoptosis [40]. Overall, there is a general consensus that PRF has a potent mitogenic activity.

\section{Migration}

There are various methods to identify the impact of PRF on cell migration including the scratch assay [70] and the traditional Boyden chamber approach [71]. Regardless of the 
Table 1 Included studies

\begin{tabular}{|c|c|c|c|c|}
\hline Study (year) & Cell type & $\begin{array}{l}\text { PRF } \\
\text { preparation }\end{array}$ & Method & Main outcome induced by PRF \\
\hline $\begin{array}{l}\text { Beitzel et al. (2014) } \\
\text { [17] }\end{array}$ & $\begin{array}{l}\text { Human mesenchymal } \\
\text { stem cells (MSCs) }\end{array}$ & $\begin{array}{l}3000 \mathrm{rpm} \\
10 \mathrm{~min} \\
\text { Hardware: } \\
\text { NR }\end{array}$ & $\begin{array}{l}\text { Cell viability by live and dead staining } \\
\text { Cell adhesion assay to the PRF-Matrix } \\
\text { Cell proliferation by incorporation of } \\
\text { 3H-thymidine }\end{array}$ & $\begin{array}{l}\text { Cell viability maintained } \\
\text { Increased cell adhesion } \\
\text { No effect in cell proliferation on collagen } \\
\text { membranes }\end{array}$ \\
\hline $\begin{array}{l}\text { Burnouf et al. } \\
\text { (2012) [18] }\end{array}$ & $\begin{array}{l}\text { Human embryonic } \\
\text { kidney fibroblasts } \\
\text { (HEK293), human } \\
\text { osteoblastic cell } \\
\text { line (MG-63), } \\
\text { SIRC, NIH/3T3, } \\
\text { periodontal } \\
\text { ligament } \\
\text { cells (PDL), } \\
\text { gingival fibroblasts } \\
\text { (GF) }\end{array}$ & $\begin{array}{l}700 \mathrm{~g} \\
12 \mathrm{~min} \\
\text { Hardware: }^{\mathrm{a}}\end{array}$ & $\begin{array}{l}\text { Cell proliferation by an automated cell } \\
\text { counter }\end{array}$ & $\begin{array}{l}\text { Increased proliferation of all cells except } \\
\text { for NIH/3T3 after } 7 \text { days of stimulation }\end{array}$ \\
\hline $\begin{array}{l}\text { Chang et al. (2010) } \\
\text { [19] }\end{array}$ & $\begin{array}{l}\text { Osteoblast cell line } \\
\text { U2OS }\end{array}$ & $\begin{array}{l}3000 \mathrm{rpm} \\
12 \mathrm{~min} \\
\text { Hardware: }^{\mathrm{a}}\end{array}$ & $\begin{array}{l}\text { Cell proliferation by MTT assay } \\
\text { Western blot for ERK phosphorylation, } \\
\text { RANKL and OPG expression }\end{array}$ & $\begin{array}{l}\text { Increased proliferation after } 1,3 \text { and } 5 \text { days } \\
\text { Increased ERK phosphorylation during } 5 \text { days } \\
\text { and OPG expression during } 3 \\
\text { days }\end{array}$ \\
\hline $\begin{array}{l}\text { Chang et al. (2011) } \\
{[20]}\end{array}$ & $\begin{array}{l}\text { Periodontal ligament } \\
\text { fibroblasts } \\
\text { (PDLFs) }\end{array}$ & $\begin{array}{l}3000 \mathrm{rpm} \\
12 \mathrm{~min} \\
\text { Hardware: }^{\mathrm{a}}\end{array}$ & $\begin{array}{l}\text { Western blot for } \mathrm{p} \text {-ERK and OPG } \\
\text { ALP activity }\end{array}$ & $\begin{array}{l}\text { Increased ERK phosphorylation and OPG } \\
\text { protein expression up to } 5 \text { days } \\
\text { Enhanced ALP activity up to } 5 \text { days }\end{array}$ \\
\hline $\begin{array}{l}\text { Clipet et al. (2012) } \\
\text { [21] }\end{array}$ & $\begin{array}{l}\mathrm{SaOS} 2 \text { (osteoblasts), } \\
\text { MRC5 (fibroblasts) } \\
\text { KB (epithelial } \\
\text { cells) }\end{array}$ & $\begin{array}{l}400 \mathrm{~g} \\
12 \mathrm{~min} \\
\text { Hardware: NR }\end{array}$ & $\begin{array}{l}\text { Cell proliferation by SRB assay } \\
\text { Cytotoxic assay by SRB assay } \\
\text { Cell cycle analysis by flow cytometry } \\
\text { tests } \\
\text { Gene expression of cbfa1, Col1, OC } \\
\text { and OP by RT-PCR }\end{array}$ & $\begin{array}{l}\text { Increased proliferation of SaOS2, MRC5 } \\
\text { and KB } \\
\text { Enhanced G2M phase in SAOS2 and } \\
\text { MRC5 lineages } \\
\text { Up-regulation of OP and OC on SAOS2 }\end{array}$ \\
\hline $\begin{array}{l}\text { Dereli et al. (2018) } \\
\quad[22]\end{array}$ & Limbal epithelial cells & $\begin{array}{l}\text { PRF gel: } 1000 \\
\text { rpm/5 min } \\
\text { PRF: } 2700 \\
\text { rpm/12 min } \\
\text { Hardware: }\end{array}$ & Cell viability by live and dead staining & Cell viability maintained \\
\hline $\begin{array}{l}\text { Dohle et al. (2018) } \\
\quad[23]\end{array}$ & $\begin{array}{l}\text { Human outgrowth } \\
\text { endothelial cells } \\
\text { (OECs) primary } \\
\text { osteoblasts (pOBs) }\end{array}$ & $\begin{array}{l}700 \mathrm{rpm} \\
3 \text { min } \\
\text { Hardware: }^{\mathrm{c}}\end{array}$ & $\begin{array}{l}\text { Co-culture of OECs with pOBs } \\
\text { Angiogenic activation by } \\
\text { immunofluorescent staining } \\
\text { ELISA for VEGF, PDGF-BB, } \\
\text { E-selectin and ICAM-1 } \\
\text { Gene expression of VEGFA, ICAM1, } \\
\text { PDGF-BB, E-selectin. BMP2 and } \\
\text { ALP by RT-PCR }\end{array}$ & $\begin{array}{l}\text { Increased VEGF concentration on pOBs } \\
\text { at } 7 \text { days } \\
\text { Increased of PDGF and E-Sel levels in } \\
\text { OECs and pOBs co-cultures at the } \\
\text { mRNA level and protein level at } 24 \\
\text { and } 72 \mathrm{~h} \\
\text { Increased expression of ICAM1 and ALP } \\
\text { at } 24 \mathrm{~h} \text { in OECs and pOBs co-cultures } \\
\text { Upregulation of VEGF expression in } \\
\text { PRF/co-culture at } 1 \text { and } 7 \text { days } \\
\text { Increased BMP2 expression in PRF co-cultures } \\
\text { cultivated at } 1 \text { and } 7 \text { days }\end{array}$ \\
\hline $\begin{array}{l}\text { Ehrenfest et al. } \\
\text { (2009) [24] }\end{array}$ & $\begin{array}{l}\text { Osteoblasts, } \\
\text { fibroblasts, } \\
\text { preadipocytes, } \\
\text { prekeratinocytes }\end{array}$ & $\begin{array}{l}400 \mathrm{~g} \\
12 \mathrm{~min} \\
\text { Hardware: }\end{array}$ & $\begin{array}{l}\text { Proliferation assay } \\
\text { Cytotoxicity by MTT assay } \\
\text { Osteoblast differentiation by Von } \\
\text { Kossa and ALP staining }\end{array}$ & $\begin{array}{l}\text { Increased proliferation of fibroblasts and } \\
\text { osteoblasts at } 3,7,14 \text { and } 21 \text { days in a } \\
\text { dose-dependent manner on osteoblasts } \\
\text { Absence of cytotoxicity in all cells } \\
\text { Increased ALP activity after } 3 \text { days and up } \\
\text { to } 28 \text { days and increased osteoblasts } \\
\text { differentiation after } 7 \text { days and up to } \\
28 \text { days }\end{array}$ \\
\hline $\begin{array}{l}\text { Ehrenfest et al. } \\
\text { (2010) [25] }\end{array}$ & $\begin{array}{l}\text { Human bone } \\
\text { mesenchymal } \\
\text { stem cells (BMSC) }\end{array}$ & $\begin{array}{l}400 \mathrm{~g} \\
12 \mathrm{~min} \\
\text { Hardware: }\end{array}$ & $\begin{array}{l}\text { Proliferation and cytotoxicity by MTT } \\
\text { assay } \\
\text { Osteoblastic differentiation by ALP } \\
\text { activity and quantification of the } \\
\text { mineralization nodules }\end{array}$ & $\begin{array}{l}\text { Increased proliferation in standard and } \\
\text { osteogenic conditions in a dose-dependent } \\
\text { manner } \\
\text { Absence of cytotoxicity on BMSC in standard } \\
\text { or osteogenic conditions }\end{array}$ \\
\hline
\end{tabular}


Table 1 (continued)

\begin{tabular}{|c|c|c|c|c|}
\hline Study (year) & Cell type & $\begin{array}{l}\text { PRF } \\
\text { preparation }\end{array}$ & Method & Main outcome induced by PRF \\
\hline
\end{tabular}

$\begin{array}{ll}\begin{array}{c}\text { Gassling et al. } \\ \text { (2013) [26] }\end{array} & \text { Human osteoblasts } \\ & \\ \text { Gassling et al. } & \text { Human periosteal } \\ \text { (2010) [27] } & \text { cells } \\ \text { He et al. (2009)[28] } & \begin{array}{c}\text { Rat calvaria } \\ \text { osteoblasts }\end{array} \\ \begin{array}{c}\text { He et al. (2016) } \\ \text { [29] }\end{array} & \begin{array}{c}\text { Human dental pulp } \\ \text { cell (hDPC) }\end{array} \\ \begin{array}{c}\text { Hong et al. (2018) } \\ \text { [30] }\end{array} & \begin{array}{l}\text { Human Stem Cells } \\ \text { of the Apical } \\ \text { Papilla (SCAPs) }\end{array}\end{array}$

Huang et al. (2010) Dental pulp cells [31]

Kang et al. (2011) [32]

\section{Khurana et al. (2017) [33]}

Kim et al. (2017)

Kim et al. (2017) [34]

\footnotetext{
Kobayashi et al. (2015) [35]
}

marrow stem cells (hABMSCs) tal (PDLSCs)

Human derived osteoblasts cells (HDPCs)

\section{$400 \mathrm{~g}$ \\ $12 \mathrm{~min}$ \\ Hardware: NR}

Cell viability by live and dead staining manner in standard and osteogenic conditions

Biocompatibility and cell proliferation Increased ALP activity

by lactate dehydrogenase, BrdDU,

MTT and WST-1

Alkaline phosphatase activity by ELISA

$400 \mathrm{~g}$

$12 \mathrm{~min}$

$2700 \mathrm{rpm}$

Hardware: ${ }^{\mathrm{d}}$

Cell viability by live and dead staining

Biocompatibility test by LDH test and MTT assay

$400 \mathrm{~g}$

$10 \mathrm{~min}$

Cell Proliferation by BrdU

Hardware: NR

Cell Proliferation

ALP activity

$400 \mathrm{~g}$

10 min

Hardware: NR

$400 \mathrm{~g}$

$10 \mathrm{~min}$

Hardware: NR

Mineralization assay by alizarin red staining

Proliferation assay by CCK-8

Gene expression of ALP and DSPP by Up-regulation of ALP and DSPP expression

RT-PCR

Cell proliferation assay

Cell migration assay

Osteogenic differentiation by alizarin red staining

Gene expression of ALP, BSP, DMP1, and DSPP by RT-PCR

$3000 \mathrm{rpm}$

$10 \mathrm{~min}$

Hardware: ${ }^{\mathrm{a}}$

Cell proliferation by MTT assay

Western blot for OPG

ALP activity assay

$400 \mathrm{~g} / 10 \mathrm{~min}$

$+230 \mathrm{~g}$

$/ 10 \mathrm{~min}$

Hardware: NR

Dental pulp stem cells $3000 \mathrm{rpm}$ (DPSCs) periodon-

$10 \mathrm{~min}$

ligament stem cells

$400 \mathrm{~g}$

10 min

Hardware: $^{\mathrm{e}}$

Cell proliferation by BrdU assay

Cell migration by wound-healing assay

Mineralization by alizarin red staining

Cell viability by trypan blue

Hardware: NR

$400 \mathrm{~g}$

$10 \mathrm{~min}$

Hardware: NR

Cell proliferation by MTT assay

Osteoblast differentiation by

Sulforhodamine B assay

ALP activity

Cell viability by MTT assay

ELISA for IL-1 $\beta$, IL-6, and IL-8

Western blot for VCAM1 and ICAM1 and odontoblastic differentiation markers DSP and DMP1

ALP Activity

Mineralization by alizarin red staining
$600 \mathrm{~g} / 2 \mathrm{~min}+$ Scratch assay
$500 \mathrm{~g} / 4 \mathrm{~min}$ Western blot for VEGFR2
$+\quad$ New blood vessel formation by CAM
$800 \mathrm{~g} / 3 \mathrm{~min} \quad$ assay

Cells seeded on PRF membranes maintained their viability

PRF membranes were biocompatible

No effect on proliferation

Increased proliferation at 5 days and enhanced mineralization at 14 days

No effect on ALP activity

Increased proliferation after 5 and 7 days

Increased proliferation at 1, 3, 5 and 7 days

Enhanced migration at 12 and $24 \mathrm{~h}$

Increased mineralization at 7 and 14 days

Down-regulation of ALP, BSP, DMP1

expression but not DSPP after 7 days

Up-regulation of ALP, BSP, DMP1 and DSPP expression after 14 days

Increased DPC proliferation at 1, 3 and 5 days

Up-regulation of OPG expression in a time-dependent manner Increased ALP activity

Increased proliferation

Reduced migration at 1 and 2 days

Enhanced mineralization

Absence of cytotoxicity at 7 days

Increased proliferation at 1, 2 and 3 days

Enhanced osteoblast differentiation

Increased ALP activity at 2 and 3 days

Absence of cytotoxicity

Reduced LPS-induced pro-inflammatory cyto-

kines IL-1b, IL-6, and IL- 8 at 1

and 3 days

and LPS-induced adhesion molecules

VCAM1 and ICAM1 at 1 day

Enhanced LPS-induced up-regulation of odontoblastic differentiation markers DSP and DMP1 at 3 days

Increased ALP activity and mineralization at day 7 in LPS treated cells

Increased migration

Enhanced phosphorylation of VEGFR2 in a dose-dependent manner

Increased number of blood capillaries 
Table 1 (continued)

\begin{tabular}{|c|c|c|c|c|}
\hline Study (year) & Cell type & $\begin{array}{l}\text { PRF } \\
\text { preparation }\end{array}$ & Method & Main outcome induced by PRF \\
\hline $\begin{array}{l}\text { Fujioka-Kobayashi } \\
\text { et al. (2017)[36] }\end{array}$ & $\begin{array}{l}\text { Human gingival } \\
\text { fibroblasts }\end{array}$ & $\begin{array}{l}\text { Hardware: }^{\mathrm{f}} \\
\text { L-PRF: } 708 \\
\text { g/12 min } \\
\text { A-PRF: } 200 \\
\text { g/14 min } \\
\text { A-PRF+: } 200 \\
\text { g/8 min } \\
\text { Hardware: }^{\mathrm{c}}\end{array}$ & $\begin{array}{l}\text { Cell viability by live-dead staining } \\
\text { Cell migration assay } \\
\text { Cell proliferation by MTS assay } \\
\text { Gene expression of TGF } \beta \text {, PDGF, and } \\
\text { COL1a2 by RT-PCR }\end{array}$ & $\begin{array}{l}\text { Cell viability maintained } \\
\text { Increased migration } \\
\text { Increased proliferation at } 3 \text { and } 5 \text { days } \\
\text { Up-regulation of PDGF and COL } 1 \mathrm{a} 2 \\
\text { expression and TGF } \beta, \text { PDGF and } \\
\text { COL1a2 at day } 7 \\
\text { A-PRF+ produced the highest expression of } \\
\text { TGF } \beta \text { and COL1a2 }\end{array}$ \\
\hline $\begin{array}{l}\text { Liang et al. (2018) } \\
\text { [37] }\end{array}$ & $\begin{array}{l}\text { Nanofat-derived } \\
\text { stem cells } \\
\text { (NFSCs) }\end{array}$ & $\begin{array}{l}2700 \mathrm{rpm} \\
12 \mathrm{~min} \\
\text { Hardware: NR }\end{array}$ & $\begin{array}{l}\text { Cell proliferation by CCK- } 8 \\
\text { Gene expression of VEGF, bFGF, } \\
\text { PDGF and TGF } \beta \text { by RT-PCR } \\
\text { Protein levels by Western blot }\end{array}$ & $\begin{array}{l}\text { Increased proliferation } \\
\text { Increased expression and protein levels of } \\
\quad \text { VEGF, bFGF, PDGF and TGF } \beta \\
\text { Enhanced osteogenic, adipogenic and } \\
\text { chondrogenic differentiation }\end{array}$ \\
\hline $\begin{array}{l}\text { Miron et al. (2017) } \\
\text { [38] }\end{array}$ & $\begin{array}{l}\text { Human gingival } \\
\text { fibroblasts } \\
\text { (HGF) }\end{array}$ & $\begin{array}{l}\text { I-PRF:700 rpm } \\
60 \mathrm{~g} \\
3 \mathrm{~min} \\
\text { Hardware: }^{\mathrm{c}}\end{array}$ & $\begin{array}{l}\text { Cell viability by live and dead assay } \\
\text { Cell migration by Boyden chamber } \\
\text { Cell proliferation by MTS assay } \\
\text { Gene expression of TGF } \beta \text {, PDGF and } \\
\text { COL1a2 by RT-PCR }\end{array}$ & $\begin{array}{l}\text { Absence of cytotoxicity } \\
\text { Increased cell migration } \\
\text { Increased proliferation after } 5 \text { days } \\
\text { Upregulation of COL } 1 \mathrm{a} 2 \text { and PDGF } \\
\text { expression after } 3 \text { days, and TGF } \beta \text { and } \\
\text { COL1a2 after } 7 \text { days }\end{array}$ \\
\hline $\begin{array}{l}\text { Moradian et al. } \\
\text { (2017) [39] }\end{array}$ & $\begin{array}{l}\text { Human bone marrow } \\
\text { mesenchymal stem } \\
\text { cells (BMMSCs) }\end{array}$ & $\begin{array}{l}400 \mathrm{~g} \\
10 \mathrm{~min} \\
\text { Hardware: NR }\end{array}$ & Cell proliferation by MTT assay & Increased proliferation at 7 days \\
\hline $\begin{array}{l}\text { Schär et al. (2015) } \\
\text { [40] }\end{array}$ & $\begin{array}{l}\text { Human bone } \\
\text { marrow-derived } \\
\text { MSC and HUVEC }\end{array}$ & $\begin{array}{l}400 \mathrm{~g} \\
12 \mathrm{~min} \\
\text { Hardware: }^{\mathrm{b}}\end{array}$ & $\begin{array}{l}\text { Cell migration assay by Boyden } \\
\text { chambers }\end{array}$ & $\begin{array}{l}\text { Increased migration of MSC and HUVEC cells } \\
\text { at } 7 \text { days and at } 8 \mathrm{~h} \text {, respectively }\end{array}$ \\
\hline $\begin{array}{l}\text { Park et al. (2018) } \\
\text { [41] }\end{array}$ & $\begin{array}{l}\text { Human umbilical } \\
\text { vein endothelial } \\
\text { cell (HUVEC) }\end{array}$ & $\begin{array}{l}400 \mathrm{~g} \\
12 \mathrm{~min} \\
\text { Hardware: }^{\mathrm{a}}\end{array}$ & $\begin{array}{l}\text { Cell proliferation by MTT assay } \\
\text { Cytotoxicity assay by adenylate kinase } \\
\text { (AK) release from dead cells } \\
\text { Cell migration by Boyden chamber } \\
\text { assay } \\
\text { Cell attachment by Green Nucleic } \\
\text { Stain-Kit }\end{array}$ & $\begin{array}{l}\text { Increased proliferation, migration and } \\
\text { attachment of cells by coating } \\
\text { porcine-matrices with PRF } \\
\text { Increased cytotoxicity at day } 1\end{array}$ \\
\hline $\begin{array}{l}\text { Passaretti et al. } \\
\text { (2014) [42] }\end{array}$ & $\begin{array}{l}\text { HUVEC, skin } \\
\text { fibroblasts }\end{array}$ & $\begin{array}{l}400 \mathrm{~g} \\
12 \mathrm{~min} \\
\text { Hardware: }^{\mathrm{a}}\end{array}$ & $\begin{array}{l}\text { Cell proliferation by Bürker chamber } \\
\text { counting and automated cell counter }\end{array}$ & Increased cell proliferation at $24 \mathrm{~h}$ \\
\hline $\begin{array}{l}\text { Saeed et al. (2017) } \\
\text { [43] }\end{array}$ & $\begin{array}{l}\text { Dental pulp stem } \\
\text { cells (DPSCs) }\end{array}$ & $\begin{array}{l}2700 \mathrm{rpm} \\
12 \mathrm{~min}+1800 \\
\mathrm{rpm} / 5 \mathrm{~min} \\
\text { Hardware: } \mathrm{NR}\end{array}$ & $\begin{array}{l}\text { Cell proliferation by MTS assay } \\
\text { Osteogenic differentiation by alizarin } \\
\text { red assay }\end{array}$ & $\begin{array}{l}\text { Reduced cell viability at } 1 \text { and } 3 \text { days by most } \\
\text { PRF concentrations } \\
\text { Enhanced osteogenic differentiation at } 7 \text { days }\end{array}$ \\
\hline $\begin{array}{l}\text { Vahabi et al. (2015) } \\
\text { [44] }\end{array}$ & $\begin{array}{l}\text { Human gingival } \\
\text { fibroblasts cell } \\
\text { line (HGF) }\end{array}$ & $\begin{array}{l}400 \mathrm{~g} \\
12 \mathrm{~min} \\
\text { Hardware: NR }\end{array}$ & $\begin{array}{l}\text { Viability and proliferation by } \\
\text { MTT assay }\end{array}$ & $\begin{array}{l}\text { Cell viability maintained during the first } 24 \mathrm{~h} \text {, } \\
\text { at } 48 \text { and } 72 \mathrm{~h} \text { cell viability is reduced } \\
\text { Increased proliferation only the first } 24 \mathrm{~h}\end{array}$ \\
\hline $\begin{array}{l}\text { Wang et al. (2018) } \\
\text { [45] }\end{array}$ & $\begin{array}{l}\text { Human primary } \\
\text { osteoblasts }\end{array}$ & $\begin{array}{l}\text { I-PRF:700 rpm } \\
60 \mathrm{~g} \\
3 \mathrm{~min} \\
\text { Hardware: }^{\mathrm{c}}\end{array}$ & $\begin{array}{l}\text { Cell viability by live and dead staining } \\
\text { Cell migration by polyethylene } \\
\text { terephthalate cell culture inserts } \\
\text { Cell adhesion assay by staining cells } \\
\text { with } 4 \text { ',6-diamidino- } 2 \text {-phenylindole } \\
\text { Cell proliferation by CCK- } 8 \\
\text { ALP activity assay } \\
\text { Mineralization by alizarin red staining } \\
\text { Gene expression of COL1A, Runx } 2 \text {, } \\
\text { ALP, OCN by RT-PCR } \\
\text { Immunofluorescence staining for OC } \\
\text { expression }\end{array}$ & $\begin{array}{l}\text { Cell viability maintained } \\
\text { Increased migration at } 1 \text { day } \\
\text { No effect on cell adhesion } \\
\text { Increased proliferation at } 3 \text { and } 5 \text { days } \\
\text { Enhanced ALP activity and mineralized nodule } \\
\quad \text { formation } \\
\text { Up-regulation of ALP expression at } 3 \text { days and } \\
\text { OCN, Runx } 2 \text { and COL1A at } 14 \text { days } \\
\text { Increased staining intensity of OCN }\end{array}$ \\
\hline $\begin{array}{l}\text { Wang et al. (2017) } \\
\text { [46] }\end{array}$ & $\begin{array}{l}\text { Human gingival } \\
\text { fibroblasts }\end{array}$ & $\begin{array}{l}700 \mathrm{rpm} \\
60 \mathrm{~g} \\
3 \mathrm{~min} \\
\text { Hardware: }^{\mathrm{c}}\end{array}$ & $\begin{array}{l}\text { Cell viability by live-dead staining as- } \\
\text { say } \\
\text { Cell migration assay by polyethylene } \\
\text { terephthalate cell culture inserts } \\
\text { Cell adhesion assay }\end{array}$ & $\begin{array}{l}\text { Cell viability maintained irrespective of the } \\
\text { titanium surface } \\
\text { Increased migration in tissue culture plates and } \\
\text { titanium surfaces } \\
\text { No effect on cell adhesion }\end{array}$ \\
\hline
\end{tabular}


Table 1 (continued)

\begin{tabular}{|c|c|c|c|c|}
\hline Study (year) & Cell type & $\begin{array}{l}\text { PRF } \\
\text { preparation }\end{array}$ & Method & Main outcome induced by PRF \\
\hline & & & $\begin{array}{l}\text { Cell proliferation by CCK- } 8 \\
\text { Gene expression of PDGF, TGF } \beta \text { and } \\
\text { COL1a1 and FN1 } \\
\text { Collagen Type I Staining } \\
\text { Immunostaining }\end{array}$ & $\begin{array}{l}\text { Increased cell proliferation after } 3 \text { and } 5 \text { days } \\
\text { Upregulation of PDGF, TGF-b, COL1 and } \\
\text { FN1 expression levels on all surfaces } \\
\text { Increased fluorescence intensity of collagen } \\
\text { type } 1 \text { on all surfaces. }\end{array}$ \\
\hline $\begin{array}{l}\text { Wei et al. (2017) } \\
\text { [47] }\end{array}$ & $\begin{array}{l}\text { Nanofat-derived } \\
\text { Stem Cells } \\
\text { (NFSCs) }\end{array}$ & $\begin{array}{l}2700 \mathrm{rpm} \\
12 \mathrm{~min} \\
\text { Hardware: NR }\end{array}$ & $\begin{array}{l}\text { Proliferation assay by CCK- } 8 \\
\text { Gene expression of adipogenic } \\
\text { differentiation markers PPAR } \gamma 2 \text {, } \\
\text { C/EBP } \alpha \text {, and ADD1 by RT-PCR }\end{array}$ & $\begin{array}{l}\text { Increased proliferation after } 3 \text { days } \\
\text { Enhanced adipogenic differentiation } \\
\text { at } 14 \text { days in a dose dependent-manner } \\
\text { Up-regulation of PPAR } \gamma 2, \mathrm{C} / \mathrm{EBP} \alpha \text {, and } \\
\text { ADD1 expression }\end{array}$ \\
\hline $\begin{array}{l}\text { Wirohadidjojo et al. } \\
\text { (2016)[48] }\end{array}$ & $\begin{array}{l}\text { Ultraviolet-A } \\
\text { (UVA)-irradiated } \\
\text { human dermal } \\
\text { fibroblasts (HDFs) }\end{array}$ & $\begin{array}{l}400 \mathrm{~g} \\
12 \mathrm{~min} \\
\text { Hardware: NR }\end{array}$ & $\begin{array}{l}\text { Proliferation assay by MTT assay } \\
\text { Collagen deposition assay } \\
\text { Cell migration rate assay }\end{array}$ & $\begin{array}{l}\text { Increased proliferation, migration and collagen } \\
\text { deposition in UVA-irradiated HDFs }\end{array}$ \\
\hline $\begin{array}{l}\text { Woo et al. (2016) } \\
\text { [49] }\end{array}$ & $\begin{array}{l}\text { Human dental pulp } \\
\text { cells (HDPCs) }\end{array}$ & $\begin{array}{l}400 \mathrm{~g} \\
10 \mathrm{~min} \\
\text { Hardware: NR }\end{array}$ & $\begin{array}{l}\text { Cell viability by MTT and MTA assay } \\
\text { ALP activity assay } \\
\text { ALP staining } \\
\text { Alizarin red staining for mineralization } \\
\text { formation } \\
\text { Western Blot for DSP,DMP1, BMP } \\
\text { 2/4, phospho-smad1/5/8 }\end{array}$ & $\begin{array}{l}\text { Cell viability maintained at } 48 \mathrm{~h} \\
\text { Increased protein levels of DSP and DMP } 1 \text { and } \\
\text { enhanced ALP activity. } \\
\text { Increased mineralization } \\
\text { Activation of BMP } 2 / 4 \text { signaling and phos- } \\
\text { phorylation of SMAD1/5/8 }\end{array}$ \\
\hline $\begin{array}{l}\text { Wu et al. (2012) } \\
\text { [50] }\end{array}$ & $\begin{array}{l}\text { Human osteoblast } \\
\text { cell line (U2OS) }\end{array}$ & $\begin{array}{l}3000 \mathrm{rpm} \\
12 \mathrm{~min} \\
\text { Hardware: }^{\mathrm{c}}\end{array}$ & $\begin{array}{l}\text { Cell attachment assay by WST-1 assay } \\
\text { Cell proliferation assay } \\
\text { Western blot analysis for p-Akt, HSP } \\
47 \text { and LOX }\end{array}$ & $\begin{array}{l}\text { Increased cell attachment the first } 3 \mathrm{~h} \\
\text { Increased proliferation at } 1,3 \text { and } 5 \text { days. } \\
\text { Enhanced Akt phosphorylation, HSP } 47 \\
\text { expression, and LOX expression in U2OS } \\
\text { cells }\end{array}$ \\
\hline $\begin{array}{l}\text { Xu et al. (2016) } \\
\text { [51] }\end{array}$ & $\begin{array}{l}\text { Human breast } \\
\text { adipose-derived } \\
\text { stem cells } \\
\text { (HBASCs) }\end{array}$ & $\begin{array}{l}2700 \mathrm{rpm} \\
12 \mathrm{~min} \\
\text { Hardware: NR }\end{array}$ & $\begin{array}{l}\text { Attachment of HBASCs on scaffolds } \\
\text { in the presence of PRF, Rg1 or both } \\
\text { by fluorescence imaging }\end{array}$ & $\begin{array}{l}\text { Increased proliferation and attachment on } \\
\text { scaffolds }\end{array}$ \\
\hline $\begin{array}{l}\text { Zhao et al. (2013) } \\
\text { [52] }\end{array}$ & $\begin{array}{l}\text { Periodontal ligament } \\
\text { stem cells } \\
\text { (PDLSCs) }\end{array}$ & $\begin{array}{l}400 \mathrm{~g} \\
10 \mathrm{~min} \\
\text { Hardware: NR }\end{array}$ & $\begin{array}{l}\text { Cell viability and proliferation assay by } \\
\text { MTT assay } \\
\text { ALP activity } \\
\text { Gene expression of BSP, OCN, ColI, } \\
\text { and CP23 by RT-PCR }\end{array}$ & $\begin{array}{l}\text { Cell viability maintained } \\
\text { Increased proliferation during } 7 \text { days } \\
\text { Reduced ALP activity at } 7 \text { days } \\
\text { Down-regulation of BSP and OCN expression } \\
\text { at } 7,14 \text { and } 21 \text { days } \\
\text { Up-regulation PDL-related genes ColI and } \\
\text { CP23 }\end{array}$ \\
\hline
\end{tabular}

Note. NR not reported, MTT 3-(4,5-Dimethylthiazol-2-Yl)-2,5-Diphenyltetrazolium Bromide, ERK extracellular signal-regulated kinase, $R A N K L$ receptor activator of NF- $\beta$ ligand, $O P G$ osteoprotegerin, $A L P$ alkaline phosphatase, $S R B$ sulforhodamine B, $c b f a 1$ core-binding factor subunit alpha- $1, L P S$ lipopolysaccharide, $V E G F$ vascular endothelial growth factor, ICAM-1 intercellular adhesion molecule 1, ELISA enzyme-linked immunosorbent assay, $B M P$ bone morphogenetic protein, $R T-P C R$ reverse transcription polymerase chain reaction, $B r d D U$ bromodeoxyuridine, WST-1 water soluble tetrazolium-1, $L D H$ lactate dehydrogenase, $C C K-8$ cell counting kit-8, $B S P$ bone sialoprotein, $D M P$ dentin matrix protein, $M T S$ 3-(4,5-dimethylthiazol-2-yl)-5(3-carboxymethoxyphenyl)-2-(4-sulfophenyl)-2H-tetrazolium), $T G F \beta$ transforming growth factor- $\beta, C O L 1 a 2$ collagen type I alpha $2, b F G F$ basic fibroblast growth factor, Runx2 runt-related transcription factor 2, $O C N$ osteocalcin, $F N 1$ fibronectin, $E C M$ extracellular matrix, $P P A R \gamma 2$ peroxisome proliferator-activated receptor, $C / E B P \alpha$ CCAAT-enhancer-binding proteins

${ }^{a}$ PC- 02, Nice, France

${ }^{\mathrm{b}}$ Hettich EBA20, Tuttlingen, Germany

${ }^{\mathrm{c}}$ Duo Centrifuge, Nice, France

${ }^{\mathrm{d}}$ Eppendorf Centrifuge 5702, Hamburg, Germany

${ }^{\mathrm{e}}$ Gyrozen 406, Daejeon, Korea

${ }^{\mathrm{f}}$ Medifuge centrifugation system, Santa Sofia, Italy 
method used, PRF increased the migration of neural stem cells [54] along with cells of the mesenchymal lineage isolated from bone [45, 64], bone marrow [72], gingiva [38, 64, 36], apical papilla [30], and skin [65, 48]. Similarly, endothelial cells responded to PRF with an increased migration [63, 72, 41]. In contrast, an inhibitory effect of PRF on cell migration was also observed on bone marrow cells but likely due to the aggregation and proliferation effect of PRF that precedes migration [32]. Likewise, in one recent study, PRF failed to induce migration on L929 fibroblasts [53]. However, the general view is that PRF supports cell motility.

\section{Alkaline phosphatase and alizarin red staining}

The main early marker of osteogenic differentiation is alkaline phosphatase [73]. Various studies showed that PRF increases the expression or the activity of alkaline phosphatase in cells of the mesenchymal lineage isolated from bone [45, ], bone marrow [25], apical papilla [30], dental pulp [31, 34, 43, 49], periodontal ligament [59, 74], osteosarcoma cell lines [21], and other tissues [24]. Moreover, PRF increased mineralized nodules in cells from dental pulp [34, 43, 49], calvaria bone [28], bone marrow [32], and periodontal ligament [59]. Conversely, one study showed an inhibitory effect of PRF on alkaline phosphatase activity [52]. In two other reports, PRF failed to change alkaline phosphatase activity and did not change alkaline phosphatase expression in rat calvaria osteoblasts [28] and bone marrow cells [40], respectively. Taken together, all but three studies reported an increase of alkaline phosphatase in response to PRF exposure.

\section{Growth factors and extracellular matrix}

PRF caused a moderate expression of various growth factors in mesenchymal and endothelial cells such as TGF $\beta[38,46$, $52,56,65,36]$, PDGF $[23,38,40,46,52,56,65,36]$, and VEGF $[23,37,58]$. Dental pulp cells treated with PRF increased expression of dentin sialoprotein and dentin matrix protein $1[29,34,49]$. With respect to changes in the expression of extracellular matrix protein, PRF increased collagen type 1 in mesenchymal cells of the bone [45], skin [65], and gingiva [38, 73]. Likewise, PRF increased the expression of osteopontin, MMP2, and MMP9 in human bone marrow cells [40]. Conversely, PRF reduced the expression of bone sialoprotein and osteocalcin along with a transient downregulation of collagen type 1 in periodontal ligament cells [52]. Similarly, a downregulation of bone sialoprotein, dentin matrix protein 1 , and dentin sialoprotein in cells from the papilla was reported [30]. It should be noted, however, that this downregulation disappeared after 14 days of stimulation [30]. In general, the reported increase of gene expression by PRF is moderate.

\section{Cell adhesion}

Cell adhesion proteins were enhanced by PRF, for example, ICAM-1 and E-selectin in cocultures of osteogenic and endothelial cells [23] and ICAM-1 in pulp cells [34]. Furthermore, PRF supported adhesion of mesenchymal cells [17], HUVEC [41], U2OS [50], and HBASC [51] on different scaffolds. These positive results nonetheless were not replicated on titanium surfaces [46] and culture plates [45]. Together, these observations suggest that in the majority of experiments, PRF could support cell adhesion.

\section{Cell signaling, inflammation, and osteoclastogenesis}

PRF enhanced the phosphorylation of Akt, heat shock protein 47 and lysis oxidase in osteosarcoma cells [50], and VEGFR2 in endothelial cells [35]. PRF enhanced phosphorylation of ERK in osteosarcoma cells [19], and periodontal fibroblasts [74] along with an increase in OPG expression in both cell types. This PRF-induced OPG expression was also reported on dental pulp cells [31]. Moreover, PRF reduced LPS-induced cytokine production in pulp cells and enhanced the up-regulation of odontoblastic differentiation markers DSP and DMP-1 in these cells [34]. Similarly, PRF suppressed the LPS- and saliva-induced pro-inflammatory cytokines on primary and RAW264.7 macrophages and attenuated the translocation of NF- $\mathrm{KB}$ into the nucleus [69]. This antiinflammatory effect was replicated in gingival fibroblasts [61]. In addition, in dental pulp cells, PRF increased DSP and DMP1 expression along with an activation of BMP 2/ 4 signaling and phosphorylation of SMAD1/5/8 cascade [49]. Osteoclasts originate from hematopoietic progenitors and in the presence of the survival factor (M-CSF) and RANKL differentiate into osteoclasts staining positive for TRAP. PRF suppressed the expression of osteoclast marker genes TRAP, DCSTAMP, NFATc, and OSCAR. Altogether, these results suggest that PRF can affect central signaling pathways, possesses an anti-inflammatory effect, and is capable of inhibiting osteoclastogenesis [57].

\section{Discussion}

This systematic review encompassed in vitro studies using PRF and can be viewed as an extension of the previous work of Miron et al. [16]. Our aim was to gather the current in vitro evidence on cellular responses to PRF. 
Table 2 Included studies

\begin{tabular}{|c|c|c|c|c|}
\hline Study (year) & Cell type & $\begin{array}{l}\text { PRF } \\
\text { preparation }\end{array}$ & Method & Main outcome induced by PRF \\
\hline $\begin{array}{l}\text { Bucur et al. } \\
\quad \text { (2019) [53] }\end{array}$ & Fibroblast cell line L929 & $\begin{array}{l}200 \mathrm{~g} \\
14 \text { min } \\
\text { Hardware: } \\
\quad \text { NR }\end{array}$ & $\begin{array}{l}\text { Cell proliferation and migration using RCTA } \\
\text { Scratch assay }\end{array}$ & $\begin{array}{l}\text { No effect on proliferation neither on } \\
\text { migration }\end{array}$ \\
\hline $\begin{array}{l}\text { Elgamal et al. } \\
\text { (2019) [47]. }\end{array}$ & $\begin{array}{l}\text { Adipose mesenchymal } \\
\text { stem cells (MSC) }\end{array}$ & $\begin{array}{l}1500 \mathrm{rpm} \\
14 \mathrm{~min} \\
\text { Hardware: } \\
\quad \text { NR }\end{array}$ & Cell proliferation by MTT assay & Increased proliferation \\
\hline $\begin{array}{l}\text { Gervois et al. } \\
\text { (2019) [54] }\end{array}$ & $\begin{array}{l}\text { Human dental pulp stem } \\
\text { cells (hDPSCs), } \\
\text { neural stem cell } \\
\text { (NSC) }\end{array}$ & $\begin{array}{l}400 \mathrm{~g} \\
12 \text { min } \\
\text { Hardware: }^{\mathrm{c}}\end{array}$ & $\begin{array}{l}\text { Metabolic activity assay by MTT assay } \\
\text { Cell proliferation by PI assay } \\
\text { Cell migration by transwell migration assay }\end{array}$ & $\begin{array}{l}\text { Decreased and increased metabolic } \\
\text { activity, dependent on the PRF } \\
\text { concentration } \\
\text { Increased proliferation of hDPSCs but } \\
\text { no effect on NSC } \\
\text { Increased migration of NSC }\end{array}$ \\
\hline $\begin{array}{l}\text { Gomez et al. } \\
\text { (2019) [55] }\end{array}$ & Endothelial cells (EC) & $\begin{array}{l}2000 \mathrm{rpm} \\
7 \mathrm{~min} \\
\text { Hardware: } \\
\quad \text { NR }\end{array}$ & $\begin{array}{l}\text { Counting of the cells viewed under phase-contrast micro- } \\
\text { scope }\end{array}$ & Increased cell growth \\
\hline $\begin{array}{l}\text { Herrera-Vizcaíno } \\
\text { et al. (2019) } \\
\text { [56] }\end{array}$ & $\begin{array}{l}\text { Human dermal vascular } \\
\text { endothelial cells } \\
\quad \text { (HDMECs) } \\
\text { Human fibroblasts (HF) }\end{array}$ & $\begin{array}{l}44 \mathrm{~g} \text { or } \\
\quad 710 \mathrm{~g} \\
8 \text { min } \\
\text { Hardware: }^{\mathrm{a}}\end{array}$ & $\begin{array}{l}\text { Immunostaining of endothelial cells marker CD } 31 \\
\text { Immunohistochemical detection of CD } 31 \\
\text { Protein levels of VEGF, PDGF-BB and TGF } \beta \text { by ELISA }\end{array}$ & $\begin{array}{l}\text { Increased CD31-positive cells } \\
\text { Increased concentration of PDGF-BB } \\
\text { of TGF } \beta \text { at day } 4 \text { in HDMECs and } \\
\text { HF } \\
\text { No effect on VEGF }\end{array}$ \\
\hline $\begin{array}{l}\text { Kargarpour et al. } \\
\text { (2019) [57] }\end{array}$ & $\begin{array}{l}\text { Murine primary } \\
\text { macrophages, } \\
\text { RAW264.7 cells }\end{array}$ & $\begin{array}{l}1570 \mathrm{rpm} \\
12 \text { min }^{\text {de }} \\
\text { Hardware: }^{\mathrm{d}}\end{array}$ & $\begin{array}{l}\text { Cell viability by MTT assay and live-dead staining } \\
\text { Cell proliferation by BrdU } \\
\text { Caspase } 3 \text { activity assay } \\
\text { Western blot for cleaved caspase } 3 \\
\text { Gene expression of osteoclast marker genes TRAP, } \\
\text { Cathepsin K, DCSTAMP, NFATc1, OSCAR and pro and } \\
\text { anti-apoptotic marker genes, caspase-3, Bax and } \\
\text { Bcl2L1 by RT-PCR } \\
\text { TRAP staining } \\
\text { Pit formation assay }\end{array}$ & $\begin{array}{l}\text { Maintenance of cell viability and } \\
\text { enhanced cell proliferation } \\
\text { Reduced caspase } 3 \text { activity and } \\
\text { suppression of cleaved caspase-3 } \\
\text { Supression of osteoclastogenesis } \\
\text { Suppression of the expression of } \\
\text { TRAP, Cathepsin K, DCSTAMP, } \\
\text { NFATc1, OSCAR } \\
\text { Reduced number of multinucleated } \\
\text { TRAP positive cells } \\
\text { Reduced pit formation on dentine } \\
\text { slices }\end{array}$ \\
\hline $\begin{array}{l}\text { Kasnak et al. } \\
\text { (2019) [58] }\end{array}$ & $\begin{array}{l}\text { Human oral } \\
\text { keratinocyte (HMK) } \\
\text { cells }\end{array}$ & $\begin{array}{l}2700 \mathrm{rpm} \\
15 \mathrm{~min} \\
\text { Hardware: }^{\mathrm{e}}\end{array}$ & $\begin{array}{l}\text { Cell proliferation by CellTiter } 96 \text { assay } \\
\text { Protein levels of IL1 } \beta \text {, IL1Ra, IL8, MCP1, and VEGF by } \\
\text { ELISA }\end{array}$ & $\begin{array}{l}\text { Increased proliferation on titanium and } \\
\text { hydroxyapatite discs } \\
\text { Increased concentration of IL1 } \beta \text {, } \\
\text { IL1Ra, IL8, MCP1, and VEGF on } \\
\text { titanium and hydroxyapatite discs }\end{array}$ \\
\hline $\begin{array}{l}\text { Li et al. (2018) } \\
\text { [59] }\end{array}$ & $\begin{array}{l}\text { Human periodontal } \\
\text { ligament cells } \\
\text { (hPDLCs) }\end{array}$ & $\begin{array}{l}750 \mathrm{~g} \\
12 \mathrm{~min}+ \\
500 \mathrm{~g} \\
5 \mathrm{~min} \\
\text { Hardware: } \\
\quad \text { NR }\end{array}$ & $\begin{array}{l}\text { Cell proliferation using CCK- } 8 \\
\text { ALP activity assay } \\
\text { Mineralization assay by alizarin red staining } \\
\text { Gene expression of RUNX2, Osterix and Osteocalcin by } \\
\text { RT-PCR } \\
\text { Protein expression of RUNX2 by Western blot }\end{array}$ & $\begin{array}{l}\text { Increased proliferation at day } 1,2 \text { and } \\
3 \\
\text { Increased ALP activity at } 7 \text { and } \\
14 \text { days } \\
\text { Increased mineralization at } 14 \text { days } \\
\text { Increased expression of RUNX2, } \\
\text { Osterix at } 5 \text { and } 7 \text { days and } \\
\text { Osteocalcin at } 7 \text { days } \\
\text { Increased protein expression of } \\
\text { RUNX2 at day } 5\end{array}$ \\
\hline $\begin{array}{l}\text { Mahendran et al. } \\
\text { (2019)[60] }\end{array}$ & Fibroblast cell line L929 & $\begin{array}{l}3000 \mathrm{rpm} \\
10 \mathrm{~min} \\
\text { Hardware: } \\
\quad \mathrm{NR}\end{array}$ & Cell viability by MTT assay & Maintenance of cell viability \\
\hline $\begin{array}{l}\text { Mudalal et al. } \\
\text { (2019) [61] }\end{array}$ & $\begin{array}{l}\text { Human gingival } \\
\text { fibroblast }\end{array}$ & $\begin{array}{l}3000 \mathrm{rpm} \\
12 \text { min } \\
\text { Hardware: }\end{array}$ & Gene expression of IL $1 \beta$, IL6 and TNF $\alpha$ by RT-PCR & $\begin{array}{l}\text { Decreased expression of IL } 1 \beta, \text { IL6 and } \\
\text { TNF } \alpha\end{array}$ \\
\hline $\begin{array}{l}\text { Nasirzade et al. } \\
\text { (2019) [62] }\end{array}$ & $\begin{array}{l}\text { Murine primary } \\
\text { macrophages, } \\
\text { Raw } 264.7 \text { cells }\end{array}$ & $\begin{array}{l}1570 \mathrm{rpm} \\
12 \mathrm{~min} \\
\text { Hardware: }^{\mathrm{d}}\end{array}$ & $\begin{array}{l}\text { Gene expression of M1 marker genes IL1 } \beta \text {, IL6; M2 genes } \\
\text { Arg1, Ym1 and lipoxygenases, ALOX12, and ALOX15 } \\
\text { by RT-PCR } \\
\text { IL6 levels by ELISA } \\
\text { NF- B intracellular translocation by Immunofluorescent }\end{array}$ & $\begin{array}{l}\text { Decreased expression of IL } 1 \beta \text { and IL6 } \\
\text { Increased expression of Arg1, Ym1 } \\
\text { and lipoxygenases } \\
\text { Increased IL6 protein level } \\
\text { Reduced intracellular translocation of } \\
\quad \text { NF- B }\end{array}$ \\
\hline
\end{tabular}


Table 2 (continued)

\begin{tabular}{|c|c|c|c|c|}
\hline Study (year) & Cell type & $\begin{array}{l}\text { PRF } \\
\text { preparation }\end{array}$ & Method & Main outcome induced by PRF \\
\hline $\begin{array}{l}\text { Ratajczak et al. } \\
\quad \text { (2018) [63] }\end{array}$ & HUVEC & $\begin{array}{l}400 \mathrm{~g} \\
12 \text { min } \\
\text { Hardware: }^{\mathrm{c}}\end{array}$ & $\begin{array}{l}\text { Cell proliferation by MTT assay and propidium iodide assay } \\
\text { Cell migration by transwell migration assay } \\
\text { Angiogenic potential by Tube Formation assay }\end{array}$ & $\begin{array}{l}\text { Increased proliferation } \\
\text { Enhanced migration } \\
\text { Increased tube formation }\end{array}$ \\
\hline $\begin{array}{l}\text { Steller et al. } \\
\text { (2019) [64] }\end{array}$ & $\begin{array}{l}\text { Primary human } \\
\text { osteoblasts (OB) }\end{array}$ & $\begin{array}{l}400 \mathrm{~g} \\
10 \mathrm{~min} \\
\text { Hardware: }\end{array}$ & $\begin{array}{l}\text { Viability by MTT assay } \\
\text { Cell adhesion to titanium surface by RTCA and cell wash } \\
\text { assay }\end{array}$ & $\begin{array}{l}\text { Maintenance of cell viability } \\
\text { No effect on adhesion to titanium } \\
\text { surface }\end{array}$ \\
\hline $\begin{array}{l}\text { Steller et al. } \\
\text { (2019) [64] }\end{array}$ & $\begin{array}{l}\text { Human gingival } \\
\text { fibroblasts (GF), } \\
\text { human osteoblasts } \\
\text { (hOB) }\end{array}$ & $\begin{array}{l}400 \mathrm{~g} \\
10 \mathrm{~min} \\
\text { Hardware: }\end{array}$ & $\begin{array}{l}\text { Cell viability by MTT assay } \\
\text { Cell migration by scratch assay }\end{array}$ & $\begin{array}{l}\text { Cell viability maintained at } 24 \text { and } \\
72 \mathrm{~h} \text { in } \mathrm{OB} \text { and at } 72 \mathrm{~h} \text { in } \mathrm{GF} \\
\text { Increased migration of } \mathrm{GF} \text { and } \mathrm{OB} \text { at } \\
24,48 \text { and } 72 \mathrm{~h} \\
\text { Increased proliferation }\end{array}$ \\
\hline $\begin{array}{l}\text { Verboket et al. } \\
\text { (2019)[40] }\end{array}$ & $\begin{array}{l}\text { Bone marrow } \\
\text { monuclear cells } \\
\text { (BMC) }\end{array}$ & $\begin{array}{l}60 \mathrm{~g} \\
3 \mathrm{~min} \\
208 \mathrm{~g} \\
8 \mathrm{~min} \\
\text { Hardware: }^{\mathrm{a}}\end{array}$ & $\begin{array}{l}\text { Metabolic activity by MTS assay } \\
\text { Gene expression of VEGFA, ICAM1, MMP2, MMP7, } \\
\text { MMP9, TGF- } \beta 1 \text {, BCL2, BAX, ALP, COL1a1, FGF23, } \\
\text { and OPN by RT-PCR } \\
\text { Determination of apoptosis using Annexin-V-staining }\end{array}$ & $\begin{array}{l}\text { Increased metabolic activity at day } 14 \\
\text { Increased expression of SPPI at day } 2 \\
\text { and } 7, \text { TGF } \beta, \text { MMP } 2 \text {, at day } 7 \text { and } \\
\text { MMP9 at day } 14 \\
\text { No effect on ICAM, ALP, COL1a1, } \\
\text { FGF23 and other genes. } \\
\text { PRF did not induce apoptosis }\end{array}$ \\
\hline $\begin{array}{l}\text { Wang et al. } \\
\text { (2019) [65] }\end{array}$ & $\begin{array}{l}\text { Dermal skin } \\
\text { fibroblast cell }\end{array}$ & $\begin{array}{l}60 \mathrm{~g} \\
3 \mathrm{~min} \\
\text { Hardware: } \\
\quad \mathrm{NR}\end{array}$ & $\begin{array}{l}\text { Cell viability using live and dead staining } \\
\text { Cell migration assay } \\
\text { Cell proliferation using CCK- } 8 \\
\text { Gene expression of PDGF, TGF } \beta \text {, COL1a1, and } \\
\text { FN1 by RT-PCR } \\
\text { Immunofluorescent staining of collagen type I }\end{array}$ & $\begin{array}{l}\text { Maintenance of cell viability } \\
\text { Increased the migration } \\
\text { Increased proliferation at day } 3 \text { and } 5 \\
\text { Increased expression of PDGF, TGF } \beta \text {, } \\
\text { COL1a1, and FN1 at } 3 \text { and } 7 \text { days. } \\
\text { Increased collagen type I staining }\end{array}$ \\
\hline
\end{tabular}

Note. NR not reported, MTT 3-(4,5-Dimethylthiazol-2-Yl)-2,5-Diphenyltetrazolium Bromide, ALP alkaline phosphatase, COL1A1 collagen 1 alpha 1, $R T-P C R$ reverse transcription polymerase chain reaction, ELISA enzyme-linked immunosorbent assay, VEGF vascular endothelial growth factor, ICAMI intercellular adhesion molecule, $S P P I$ osteopontin, $P D G F-B B$ platelet-derived growth factor, $P I$ propodeum iodide, $B D N F$ brain-derived neurotrophic factor, $C C K-8$ cell counting kit- $8, T G F \beta$ transforming growth factor- $\beta, T R A P$ tartrate-resistant acid phosphatase, DCSTAMP dendritic cell-specific transmembrane protein, NFATCl nuclear factor of activated T-cells, OSCAR osteoclast-associated receptor, Bax Bcl2-associated x protein, Bcl2 B cell lymphoma 2, MCP-1 monocyte chemotactic protein-1, MTS 3-(4,5-dimethylthiazol-2-yl)-5-(3-carboxymethoxyphenyl)-2-(4-sulfophenyl)-2H-tetrazolium), $F G F 23$ basic fibroblast growth factor, $T N F$ - $\alpha$ tumor necrosis factor, Arg 1 arginase-1, $A L O X$ arachidonate lypoxigenase, $N F$ nuclear factor kappalight-chain-enhancer of activated B cells, $R T C A$ real-time-cell analyzer assay, $M$ - $C S F$ macrophage colony stimulating factor, $M M P$ matrix metalloproteinase, FN1 fibronectin

${ }^{a}$ Duo Centrifuge, Nice, France

${ }^{\mathrm{b}}$ Eppendorf Centrifuge 5702, Hamburg, Germany

${ }^{\mathrm{c}}$ Intraspin TM, Intra-Lock International, Boca Raton, FL

${ }^{\mathrm{d}}$ Z 306 Hermle Universal Centrifuge, Wehingen, Germany

${ }^{\mathrm{e}}$ SL8R, Thermo Fisher Scientific, Waltham, MA

${ }^{\mathrm{f}}$ Allegra X-12R-Centrifuge, Brea, California

Despite the steadily increasing number of in vitro studies, much of the available evidence has focused on confirming similar findings. The majority of studies assessed the impact of PRF on proliferation, adhesion, migration, and differentiation mainly on mesenchymal cells and to some extent, endothelial and epithelial cells. Overall, PRF triggered an increase in the abovementioned parameters and revealed anti-inflammatory properties. PRF also showed a moderate but consistent capacity to modulate the expression of target genes activating different signaling pathways.

A meta-analysis could not be performed as the included studies revealed heterogeneity in terms of study design, evaluation methods, outcome measures, and observation periods. Besides the original L-PRF protocol, other PRF protocols were used, however, most studies did not provide enough details. These details are of importance as with different protocols [3], i.e., centrifugation time and g-force, characteristics such as the release of growth factors or the content of living cells are substantially changed [75]. For instance, by reducing the $\mathrm{g}$-force, there is an improvement in growth release and cell content. This finding is considered one of the major innovations in PRF leading to the development of new protocols including advanced platelet-rich fibrin (A-PRF+), injectable PRF (i-PRF), and liquid PRF (fluid-PRF). In addition, there are other factors that were not considered in the different 
preparation protocols such as the centrifugation tubes which have a strong impact on the clot size [76]. Indeed, the silica used to coat plastic tubes might contaminate PRF and thereby provoking inflammation [77]. Likewise, differences in g-forces, blood volume, hematocrit levels, centrifugation time, and handling of PRF membranes impede an accurate comparison between the protocols. Furthermore, PRF lysates, PRF conditioned medium, and PRF exudates should also be distinguished from traditional protocols. Although these issues are at the heart of scientific discussion $[78,79]$, the main in vitro findings are rather consistent.

Successful tissue regeneration and osseointegration rely on the response of the surrounding cells. These biological processes inevitably require proliferation, migration, and differentiation of cells at the treatment site.

PRF consistently increased cell proliferation irrespective of the cell type and PRF preparation. One interesting setting was the increased cell proliferation on collagen matrices [72] and titanium surfaces [46] upon PRF coating. It is worth noting that two studies found a conspicuously reduced proliferation in gingival fibroblast [44] and dental pulp stem cells [43]. It is difficult, however, to determine why PRF led to a decline in cell proliferation. PRF membranes covering cells might decrease oxygenation [44]. Nonetheless, PRF preparation without providing enough details complicates the interpretation of the data [43]. Despite these shortcomings, the majority of the in vitro studies suggest a mitogenic activity of PRF for various cell types that might be attributed to the strong mitogen PDGF released by activated platelets $[13,80]$.

Cell migration was positively induced in all but two of the selected studies. This chemotactic effect is likely due to the presence of growth factors contained in platelets such as PDGF [12]. This growth factor, for example, pushes proliferation of osteogenic cells in vitro [81]. In addition, endothelial cells followed a similar pattern of displaying an increase in migration upon exposure to PRF [40]. Although the activation of platelets might account for these observations [11], the precise mechanism remains to be elucidated. In support of the mitogenic and chemotactic activity, PRF enhanced the phosphorylation of Akt [50], and ERK [19,74] similar to what is observed in isolated platelets [12]. Conversely, inhibition of migration by PRF has been reported in alveolar bone marrow cells [32]. This effect might be explained by the aggregation and proliferation effect of PRF that precedes migration and also by methodological differences, which precludes an interpretation and a comparison with the other studies [3]. Despite these inconsistencies, PRF is able to induce cell migration, likely due to the presence of growth factors such as PDGF with chemotactic activity.

Cell differentiation is commonly assessed by means of measuring alkaline phosphatase and alizarin red staining. Various studies showed that PRF increases the expression or the activity of alkaline phosphatase in cells of the mesenchymal lineage $[24,25,29-31,34,43,45,49,65,59$, 74]. Some data, nonetheless, are conflicting since PRF can also reduce alkaline phosphatase activity [52] consistent with the effects of supernatants of isolated platelets [12]. This reduction may be attributed to TGF- $\beta$ [82] and PDGF [12]. On the other hand, the increased mineralized nodules elicited by PRF in cells from dental pulp [34, 43, 49], calvaria bone [28], bone marrow [32], and periodontal ligament [59] appear to be a consequence of the enhanced proliferation, alkaline phosphatase activity, and production of collagen matrix. These in vitro findings, however, have to be interpreted with caution as proliferation and differentiation do not occur simultaneously [73].

With respect to growth factors such as TGF $\beta$, PDGF, and VEGF, PRF moderately increased their expression. Regarding extracellular matrix proteins, PRF moderately increased the expression of collagen type 1 , which is a known TGF $\beta$ target gene $[83,84]$ in mesenchymal cells of various origins. In line with collagen type 1 synthesis, PRF activates the expression of HSP47 and lysine oxidase [50]. Cell adhesion proteins were enhanced by PRF [23], however, they are not necessarily responsible for the increased cell adhesion on different scaffolds [51]. Together, these observations suggest that PRF induces moderate changes in gene expression. In contrast, recent data at our lab indicate a robust activation of TGF $\beta$ target genes IL11, PRG4, and NOX4 by PRF lysates (Di Summa et al. unpublished observation). TGF- $\beta$ couples osteogenesis with angiogenesis by providing a pro-osteogenic microenvironment in vivo [62]. As TGF- $\beta$ induces pro-osteogenic factors and TGF- $\beta$ type 1 receptor inhibitor rescues uncoupled bone remodeling in vivo [62], PRF-derived TGF- $\beta$ may support bone regeneration.

This systematic review revealed an anti-inflammatory effect of PRF. Moreover, during the submission process of the present review, new studies were published highlighting these anti-inflammatory effects of PRF. For example, PRF reduced the LPS-induced proinflammatory cytokine release in gingival fibroblasts [61]. In addition, we have recently shown that PRF reduces the expression of the M1 marker genes interleukin $1 \beta$ (IL1 $\beta$ ) and interleukin 6 (IL6) in bone marrow macrophages [69]. This anti-inflammatory effect might be explained by the high amounts of TGF $\beta$ in PRF [73] capable of modulating the M1 and M2 polarization along with the generation of proresolving lipid mediators [69]. Additionally, PRF induces the expression of the M2 markers arginase- 1 and chitinaselike 3 (Chil3 or YM1) thereby assisting a M1-to-M2 transition [69]. Since dental implants activate the immune system during the early stages of osseointegration [85], the addition of PRF may support a M2 polarization reducing the time lag for osseointegration and bone regeneration. Notably, PRF can also decrease the formation of osteoclast-like cell in a murine bone marrow culture [57]. Similar findings were also reported in peripheral blood mononuclear cells derived $\mathrm{CD} 14^{+}$cells 
[86]. These observations are of particular interest since the favorable effects of PRF in alveolar ridge preservation [6] might be partly explained by an inhibition of osteoclastogenesis. Thus, accumulating evidence suggest that PRF possesses an anti-inflammatory activity and is capable of suppressing osteoclastogenesis.

PRF is a potent inducer of the in vitro angiogenic process indicated by endothelial proliferation, migration, and tube formation. PRF supports microvessel-like structures $[23,56]$ and induces blood vessel formation in the chorioallantoic membrane assay [63]. Apart from in vitro angiogenesis, a recent report described an antimicrobial effect of PRF. In that study, both PRF membranes and PRF exudates had an antimicrobial effect against $P$. gingivalis, a key periodontal pathogen [87]. Those findings support the rationale of using PRF as an adjunctive therapy for peri-implantitis [88]. These observations are also in line with previous data on purified activated platelet showing an angiogenic [11] and antimicrobial effect [89]. Overall, these findings imply that PRF possesses angiogenic and antimicrobial properties.

We recognize that the present report has a number of limitations. PRF is widely used in regenerative dentistry, however, in vitro models represent only a narrow aspect of wound healing and bone regeneration neglecting the holistic nature of an in vivo model. Furthermore, and considering that wound healing and bone regeneration involve granulocytes, lymphocytes and other cell types, today's PRF research only covers a restricted spectrum of cells. It should also be noted that the same stimuli may play different roles depending on the differentiation stage of the target cell. For example, our group demonstrated that PRF membranes inhibit the formation of osteoclasts in bone marrow cultures [57]. This inhibition, however, did not occur when osteoclastogenesis had already started [57].

Future studies should, for example, include research on the immigration and activation of granulocytes and how PRF might control the resolution of inflammation. Moreover, and considering the importance of centrifugation tubes and the possible impact of silica coating, more studies investigating this issue are needed for the optimization of PRF. Finally, the overall question of whether the in vitro PRF research reflects the clinical reality serving as a surrogate parameter to adapt the current PRF protocols remains to be clarified.

\section{Conclusion}

Despite some notable differences of the included studies, the overall findings suggest a benefit of PRF on cell proliferation, migration, adhesion, differentiation, and inflammation pointing towards a therapeutic potential in wound healing and regeneration.
Author contributions F.J.S. and R.G. contributed to conception and design; contributed to the literature research, analysis, and interpretation; drafted manuscript; critically revised manuscript; gave final approval; agreed to be accountable for all aspects of work. J.N. and Z.K. literature research, analysis, and interpretation; critically revised manuscript; gave final approval; agreed to be accountable for all aspects of work. A.S. analysis, and interpretation; critically revised manuscript; gave final approval; agreed to be accountable for all aspects of work.

Funding information Open access funding provided by Austrian Science Fund (FWF). This study was funded by a grant (17-125) from the Osteology Foundation, Switzerland. This research was further supported by a grant from Austrian Science Fund (FWF) (4072-B28). Franz Josef Strauss is supported by the Osteology Foundation and the Comisión Nacional de Investigación Científica y Tecnológica (CONICYT), Chile. Jila Nasirzade and Zahra Kargarpour received support from the Osteology Foundation (17-125), Switzerland. Alexandra Stähli received grants from the Swiss Dental Association (288-15), the Swiss Society of Periodontology (SSP), the Foundation for the Promotion of Oral Health and Research as well as the Osteology Foundation.

\section{Compliance with ethical standards}

Conflict of interest All authors declare that they have no conflict of interest.

Ethical approval This article does not contain any studies with human participants or animals performed by any of the authors.

Informed consent For this type of study, formal consent is not required.

Open Access This article is licensed under a Creative Commons Attribution 4.0 International License, which permits use, sharing, adaptation, distribution and reproduction in any medium or format, as long as you give appropriate credit to the original author(s) and the source, provide a link to the Creative Commons licence, and indicate if changes were made. The images or other third party material in this article are included in the article's Creative Commons licence, unless indicated otherwise in a credit line to the material. If material is not included in the article's Creative Commons licence and your intended use is not permitted by statutory regulation or exceeds the permitted use, you will need to obtain permission directly from the copyright holder. To view a copy of this licence, visit http://creativecommons.org/licenses/by/4.0/.

\section{References}

1. Dohan DM, Choukroun J, Diss A, Dohan SL, Dohan AJ, Mouhyi J, Gogly B (2006) Platelet-rich fibrin (PRF): a second-generation platelet concentrate. Part I: technological concepts and evolution. Oral Surg Oral Med Oral Pathol Oral Radiol Endod 101(3):e37e44. https://doi.org/10.1016/j.tripleo.2005.07.008

2. Miron RJ, Chai J, Zheng S, Feng M, Sculean A, Zhang Y (2019) A novel method for evaluating and quantifying cell types in platelet rich fibrin and an introduction to horizontal centrifugation. J Biomed Mater Res A 107(10):2257-2271. https://doi.org/10. 1002/jbm.a.36734

3. Miron RJ, Pinto NR, Quirynen M, Ghanaati S (2019) Standardization of relative centrifugal forces in studies related to platelet-rich fibrin. J Periodontol. https://doi.org/10.1002/JPER.180553 
4. Castro AB, Meschi N, Temmerman A, Pinto N, Lambrechts P, Teughels W, Quirynen M (2017) Regenerative potential of leucocyte- and platelet-rich fibrin. Part A: intra-bony defects, furcation defects and periodontal plastic surgery. A systematic review and meta-analysis. J Clin Periodontol 44(1):67-82. https://doi.org/ $10.1111 /$ jcpe. 12643

5. Strauss FJ, Stahli A, Gruber R (2018) The use of platelet-rich fibrin to enhance the outcomes of implant therapy: a systematic review. Clin Oral Implants Res 29(Suppl 18):6-19. https://doi.org/10.1111/ clr. 13275

6. Temmerman A, Vandessel J, Castro A, Jacobs R, Teughels W, Pinto N, Quirynen M (2016) The use of leucocyte and platelet-rich fibrin in socket management and ridge preservation: a split-mouth, randomized, controlled clinical trial. J Clin Periodontol 43(11):990999. https://doi.org/10.1111/jcpe.12612

7. Öncü E, Alaaddinoglu EE (2015) The effect of platelet-rich fibrin on implant stability. The International Journal of Oral \& Maxillofacial Implants 30(3):578-582. https://doi.org/10.11607/ jomi.3897

8. Tabrizi R, Arabion H, Karagah T (2017) Does platelet-rich fibrin increase the stability of implants in the posterior of the maxilla? A split-mouth randomized clinical trial. Int J Oral Maxillofac Surg. https://doi.org/10.1016/j.ijom.2017.07.025

9. Temmerman A, Cleeren GJ, Castro AB, Teughels W, Quirynen M (2018) L-PRF for increasing the width of keratinized mucosa around implants: a split-mouth, randomized, controlled pilot clinical trial. J Periodontal Res 53(5):793-800. https://doi.org/10.1111/ jre. 12568

10. Kolar P, Schmidt-Bleek K, Schell H, Gaber T, Toben D, Schmidmaier G, Perka C, Buttgereit F, Duda GN (2010) The early fracture hematoma and its potential role in fracture healing. Tissue Eng Part B Rev 16(4):427-434. https://doi.org/10.1089/ten.TEB. 2009.0687

11. Kandler B, Fischer MB, Watzek G, Gruber R (2004) Plateletreleased supernatant increases matrix metalloproteinase-2 production, migration, proliferation, and tube formation of human umbilical vascular endothelial cells. J Periodontol 75(9):1255-1261. https://doi.org/10.1902/jop.2004.75.9.1255

12. Gruber R, Karreth F, Kandler B, Fuerst G, Rot A, Fischer MB, Watzek G (2004) Platelet-released supernatants increase migration and proliferation, and decrease osteogenic differentiation of bone marrow-derived mesenchymal progenitor cells under in vitro conditions. Platelets 15(1):29-35. https://doi.org/10.1080/ 09537100310001643999

13. Gruber R, Varga F, Fischer MB, Watzek G (2002) Platelets stimulate proliferation of bone cells: involvement of platelet-derived growth factor, microparticles and membranes. Clin Oral Implants Res 13(5):529-535

14. Alsousou J, Thompson M, Hulley P, Noble A, Willett K (2009) The biology of platelet-rich plasma and its application in trauma and orthopaedic surgery: a review of the literature. J Bone Joint Surg (Br) 91(8):987-996. https://doi.org/10.1302/0301-620X.91B8. 22546

15. Nikolidakis D, Jansen JA (2008) The biology of platelet-rich plasma and its application in oral surgery: literature review. Tissue Eng Part B Rev 14(3):249-258. https://doi.org/10.1089/ten.teb.2008. 0062

16. Miron RJ, Fujioka-Kobayashi M, Bishara M, Zhang Y, Hernandez M, Choukroun J (2017) Platelet-rich fibrin and soft tissue wound healing: a systematic review. Tissue Eng Part B Rev 23(1):83-99. https://doi.org/10.1089/ten.TEB.2016.0233

17. Beitzel K, McCarthy MB, Cote MP, Russell RP, Apostolakos J, Ramos DM, Kumbar SG, Imhoff AB, Arciero RA, Mazzocca AD (2014) Properties of biologic scaffolds and their response to mesenchymal stem cells. Arthroscopy 30(3):289-298. https://doi.org/ 10.1016/j.arthro.2013.11.020
18. Burnouf T, Lee CY, Luo CW, Kuo YP, Chou ML, Wu YW, Tseng YH, Su CY (2012) Human blood-derived fibrin releasates: composition and use for the culture of cell lines and human primary cells. Biologicals 40(1):21-30. https://doi.org/10.1016/j.biologicals. 2011.09.017

19. Chang IC, Tsai CH, Chang YC (2010) Platelet-rich fibrin modulates the expression of extracellular signal-regulated protein kinase and osteoprotegerin in human osteoblasts. J Biomed Mater Res A 95(1):327-332. https://doi.org/10.1002/jbm.a.32839

20. Chang YC, Zhao JH (2011) Effects of platelet-rich fibrin on human periodontal ligament fibroblasts and application for periodontal infrabony defects. Australian dental journal 56 (4):365-371. https://doi.org/10.1111/j.1834-7819.2011.01362.x

21. Clipet F, Tricot S, Alno N, Massot M, Solhi H, Cathelineau G, Perez F, De Mello G, Pellen-Mussi P (2012) In vitro effects of Choukroun's platelet-rich fibrin conditioned medium on 3 different cell lines implicated in dental implantology. Implant Dent 21(1): 51-56. https://doi.org/10.1097/ID.0b013e31822b9cb4

22. Dereli Can G, Akdere OE, Can ME, Aydin B, Cagil N, Gumusderelioglu M (2018) A completely human-derived biomaterial mimicking limbal niche: platelet-rich fibrin gel. Exp Eye Res 173:1-12. https://doi.org/10.1016/j.exer.2018.04.013

23. Dohle E, El Bagdadi K, Sader R, Choukroun J, James Kirkpatrick C, Ghanaati S (2018) Platelet-rich fibrin-based matrices to improve angiogenesis in an in vitro co-culture model for bone tissue engineering. J Tissue Eng Regen Med 12(3):598-610. https://doi.org/ 10.1002/term. 2475

24. Dohan Ehrenfest DM, Diss A, Odin G, Doglioli P, Hippolyte MP, Charrier JB (2009) In vitro effects of Choukroun's PRF (plateletrich fibrin) on human gingival fibroblasts, dermal prekeratinocytes, preadipocytes, and maxillofacial osteoblasts in primary cultures. Oral Surg Oral Med Oral Pathol Oral Radiol Endod 108(3):341352. https://doi.org/10.1016/j.tripleo.2009.04.020

25. Dohan Ehrenfest DM, Doglioli P, de Peppo GM, Del Corso M, Charrier JB (2010) Choukroun's platelet-rich fibrin (PRF) stimulates in vitro proliferation and differentiation of human oral bone mesenchymal stem cell in a dose-dependent way. Arch Oral Biol 55(3):185-194. https://doi.org/10.1016/j.archoralbio.2010.01.004

26. Gassling V, Hedderich J, Acil Y, Purcz N, Wiltfang J, Douglas T (2013) Comparison of platelet rich fibrin and collagen as osteoblastseeded scaffolds for bone tissue engineering applications. Clin Oral Implants Res 24(3):320-328. https://doi.org/10.1111/j.1600-0501. 2011.02333.x

27. Gassling V, Douglas T, Warnke PH, Acil Y, Wiltfang J, Becker ST (2010) Platelet-rich fibrin membranes as scaffolds for periosteal tissue engineering. Clin Oral Implants Res 21(5):543-549. https:// doi.org/10.1111/j.1600-0501.2009.01900.x

28. He L, Lin Y, Hu X, Zhang Y, Wu H (2009) A comparative study of platelet-rich fibrin (PRF) and platelet-rich plasma (PRP) on the effect of proliferation and differentiation of rat osteoblasts in vitro. Oral Surg Oral Med Oral Pathol Oral Radiol Endod 108(5):707713. https://doi.org/10.1016/j.tripleo.2009.06.044

29. He X, Chen WX, Ban G, Wei W, Zhou J, Chen WJ, Li XY (2016) A new method to develop human dental pulp cells and platelet-rich fibrin complex. J Endod 42(11):1633-1640. https://doi.org/10. 1016/j.joen.2016.08.011

30. Hong S, Chen W, Jiang B (2018) A comparative evaluation of concentrated growth factor and platelet-rich fibrin on the proliferation, migration, and differentiation of human stem cells of the apical papilla. J Endod 44(6):977-983. https://doi.org/10.1016/j.joen. 2018.03.006

31. Huang FM, Yang SF, Zhao JH, Chang YC (2010) Platelet-rich fibrin increases proliferation and differentiation of human dental pulp cells. J Endod 36(10):1628-1632. https://doi.org/10.1016/j. joen.2010.07.004 
32. Kang YH, Jeon SH, Park JY, Chung JH, Choung YH, Choung HW, Kim ES, Choung PH (2011) Platelet-rich fibrin is a bioscaffold and reservoir of growth factors for tissue regeneration. Tissue Eng Part A 17(3-4):349-359. https://doi.org/10.1089/ten.TEA.2010.0327

33. Khurana R, Kudva PB, Husain SY (2017) Comparative evaluation of the isolation and quantification of stem cells derived from dental pulp and periodontal ligament of a permanent tooth and to assess their viability and proliferation on a platelet-rich fibrin scaffold. J Indian Soc Periodontol 21(1):16-20. https://doi.org/10.4103/jisp. jisp 18216

34. Kim JH, Woo SM, Choi NK, Kim WJ, Kim SM, Jung JY (2017) Effect of platelet-rich fibrin on odontoblastic differentiation in human dental pulp cells exposed to lipopolysaccharide. J Endod 43(3):433-438. https://doi.org/10.1016/j.joen.2016.11.002

35. Kobayashi M, Kawase T, Okuda K, Wolff LF, Yoshie H (2015) In vitro immunological and biological evaluations of the angiogenic potential of platelet-rich fibrin preparations: a standardized comparison with PRP preparations. Int J Implant Dent 1(1):31. https://doi. org/10.1186/s40729-015-0032-0

36. Schar MO, Diaz-Romero J, Kohl S, Zumstein MA, Nesic D (2015) Platelet-rich concentrates differentially release growth factors and induce cell migration in vitro. Clin Orthop Relat Res 473(5):16351643. https://doi.org/10.1007/s11999-015-4192-2

37. Liang ZJ, Lu X, Li DQ, Liang YD, Zhu DD, Wu FX, Yi XL, He N, Huang YQ, Tang C, Li HM (2018) Precise intradermal injection of nanofat-derived stromal cells combined with platelet-rich fibrin improves the efficacy of facial skin rejuvenation. Cell Physiol Biochem 47(1):316-329. https://doi.org/10.1159/000489809

38. Miron RJ, Fujioka-Kobayashi M, Hernandez M, Kandalam U, Zhang Y, Ghanaati S, Choukroun J (2017) Injectable platelet rich fibrin (i-PRF): opportunities in regenerative dentistry? Clin Oral Investig 21(8):2619-2627. https://doi.org/10.1007/s00784-0172063-9

39. Kim J, Ha Y, Kang NH (2017) Effects of growth factors from platelet-rich fibrin on the bone regeneration. J Craniofac Surg 28(4):860-865. https://doi.org/10.1097/SCS.0000000000003396

40. Verboket R, Herrera-Vizcaino C, Thorwart K, Booms P, Bellen M, Al-Maawi S, Sader R, Marzi I, Henrich D, Ghanaati S (2019) Influence of concentration and preparation of platelet rich fibrin on human bone marrow mononuclear cells (in vitro). Platelets 30(7):861-870. https://doi.org/10.1080/09537104.2018.1530346

41. Fujioka-Kobayashi M, Miron RJ, Hernandez M, Kandalam U, Zhang Y, Choukroun J (2017) Optimized platelet-rich fibrin with the low-speed concept: growth factor release, biocompatibility, and cellular response. J Periodontol 88(1):112-121. https://doi.org/10. 1902/jop.2016.160443

42. Passaretti F, Tia M, D'Esposito V, De Pascale M, Del Corso M, Sepulveres R, Liguoro D, Valentino R, Beguinot F, Formisano P, Sammartino G (2014) Growth-promoting action and growth factor release by different platelet derivatives. Platelets 25(4):252-256. https://doi.org/10.3109/09537104.2013.809060

43. Saeed MA, El-Rahman MA, Helal ME, Zaher AR, Grawish ME (2017) Efficacy of human platelet rich fibrin exudate vs fetal bovine serum on proliferation and differentiation of dental pulp stem cells. Int J Stem Cells 10(1):38-47. https://doi.org/10.15283/ijsc16067

44. Vahabi S, Vaziri S, Torshabi M, Rezaei Esfahrood Z (2015) Effects of plasma rich in growth factors and platelet-rich fibrin on proliferation and viability of human gingival fibroblasts. J Dent (Tehran) 12(7):504-512

45. Wang X, Zhang Y, Choukroun J, Ghanaati S, Miron RJ (2018) Effects of an injectable platelet-rich fibrin on osteoblast behavior and bone tissue formation in comparison to platelet-rich plasma. Platelets 29(1):48-55. https://doi.org/10.1080/09537104.2017. 1293807

46. Wang X, Zhang Y, Choukroun J, Ghanaati S, Miron RJ (2017) Behavior of gingival fibroblasts on titanium implant surfaces in combination with either injectable-PRF or PRP. Int J Mol Sci 18(2). https://doi.org/10.3390/ijms18020331

47. Wei H, Gu SX, Liang YD, Liang ZJ, Chen H, Zhu MG, Xu FT, He N, Wei XJ, Li HM (2017) Nanofat-derived stem cells with plateletrich fibrin improve facial contour remodeling and skin rejuvenation after autologous structural fat transplantation. Oncotarget 8(40): 68542-68556. https://doi.org/10.18632/oncotarget.19721

48. Wirohadidjojo YW, Budiyanto A, Soebono H (2016) Platelet-rich fibrin lysate can ameliorate dysfunction of chronically UVAirradiated human dermal fibroblasts. Yonsei Med J 57(5):12821285. https://doi.org/10.3349/ymj.2016.57.5.1282

49. Woo SM, Kim WJ, Lim HS, Choi NK, Kim SH, Kim SM, Jung JY (2016) Combination of mineral trioxide aggregate and platelet-rich fibrin promotes the odontoblastic differentiation and mineralization of human dental pulp cells via BMP/Smad signaling pathway. J Endod 42(1):82-88. https://doi.org/10.1016/j.joen.2015.06.019

50. Wu CL, Lee SS, Tsai CH, Lu KH, Zhao JH, Chang YC (2012) Platelet-rich fibrin increases cell attachment, proliferation and collagen-related protein expression of human osteoblasts. Aust Dent J 57(2):207-212. https://doi.org/10.1111/j.1834-7819.2012. 01686.x

51. Xu FT, Liang ZJ, Li HM, Peng QL, Huang MH, Li de Q, Liang YD, Chi GY, Li de H, Yu BC, Huang JR (2016) Ginsenoside Rg1 and platelet-rich fibrin enhance human breast adipose-derived stem cell function for soft tissue regeneration. Oncotarget 7(23):35390 35403. https://doi.org/10.18632/oncotarget.9360

52. Zhao YH, Zhang M, Liu NX, Lv X, Zhang J, Chen FM, Chen YJ (2013) The combined use of cell sheet fragments of periodontal ligament stem cells and platelet-rich fibrin granules for avulsed tooth reimplantation. Biomaterials 34(22):5506-5520. https://doi. org/10.1016/j.biomaterials.2013.03.079

53. Bucur M, Constantin C, Neagu M, Zurac S, Dinca O, Vladan C, Cioplea M, Popp C, Nichita L, Ionescu E (2019) Alveolar blood clots and platelet-rich fibrin induce in vitro fibroblast proliferation and migration. Exp Ther Med 17(2):982-989. https://doi.org/10. 3892/etm.2018.7063

54. Gervois P, Ratajczak J, Wolfs E, Vangansewinkel T, Dillen Y, Merckx G, Bronckaers A, Lambrichts I (2019) Preconditioning of human dental pulp stem cells with leukocyte- and platelet-rich fibrin-derived factors does not enhance their neuroregenerative effect. Stem Cells Int 2019:8589149. https://doi.org/10.1155/2019/ 8589149

55. Gomez TW, Gopal RV, Gaffoor FMA, Kumar STR, Girish CS, Prakash R (2019) Comparative evaluation of angiogenesis using a novel platelet-rich product: an in vitro study. J Conserv Dent 22(1): 23-27. https://doi.org/10.4103/JCD.JCD_216_18

56. Herrera-Vizcaino C, Dohle E, Al-Maawi S, Booms P, Sader R, Kirkpatrick CJ, Choukroun J, Ghanaati S (2019) Platelet-rich fibrin secretome induces three dimensional angiogenic activation in vitro. Eur Cell Mater 37:250-264. https://doi.org/10.22203/eCM. v037a15

57. Kargarpour Z, Nasirzade J, Strauss FJ, Di Summa F, Hasannia S, Muller HD, Gruber R (2019) Platelet-rich fibrin suppresses in vitro osteoclastogenesis. J Periodontol. https://doi.org/10.1002/JPER.190109

58. Kasnak G, Fteita D, Jaatinen O, Kononen E, Tunali M, Gursoy M, Gursoy UK (2019) Regulatory effects of PRF and titanium surfaces on cellular adhesion, spread, and cytokine expressions of gingival keratinocytes. Histochem Cell Biol 152(1):63-73. https://doi.org/ 10.1007/s00418-019-01774-8

59. Li X, Yang H, Zhang Z, Yan Z, Lv H, Zhang Y, Wu B (2018) Plateletrich fibrin exudate promotes the proliferation and osteogenic differentiation of human periodontal ligament cells in vitro. Mol Med Rep 18(5):4477-4485. https://doi.org/10.3892/mmr.2018. 9472 
60. Mahendran K, Kottuppallil G, Sekar V (2019) Comparative evaluation of radiopacity and cytotoxicity of platelet-rich fibrin, plateletrich fibrin $+50 \mathrm{wt} \%$ nano-hydroxyapatite, platelet-rich fibrin + 50wt\% dentin chips: An in vitro study. J Conserv Dent 22 (1):2833. https://doi.org/10.4103/JCD.JCD 28118

61. Mudalal M, Sun X, Li X, Zhou Y (2019) The evaluation of leukocyte-platelet rich fibrin as an anti-inflammatory autologous biological additive. A novel in vitro study. Saudi Med J 40(7): 657-668. https://doi.org/10.15537/smj.2019.7.24302

62. Qin Y, Tang S, Zhen G, Ding Q, Ding S, Cao X (2018) Bonetargeted delivery of TGF-beta type 1 receptor inhibitor rescues uncoupled bone remodeling in Camurati-Engelmann disease. Ann N Y Acad Sci 1433(1):29-40. https://doi.org/10.1111/nyas.13941

63. Ratajczak J, Vangansewinkel T, Gervois P, Merckx G, Hilkens P, Quirynen M, Lambrichts I, Bronckaers A (2018) Angiogenic properties of 'leukocyte- and platelet-rich Fibrin'. Sci Rep 8(1):14632. https://doi.org/10.1038/s41598-018-32936-8

64. Steller D, Herbst N, Pries R, Juhl D, Hakim SG (2019) Positive impact of platelet-rich plasma and platelet-rich fibrin on viability, migration and proliferation of osteoblasts and fibroblasts treated with zoledronic acid. Sci Rep 9(1):8310. https://doi.org/10.1038/ s41598-019-43798-Z

65. Wang X, Yang Y, Zhang Y, Miron RJ (2019) Fluid platelet-rich fibrin stimulates greater dermal skin fibroblast cell migration, proliferation, and collagen synthesis when compared to platelet-rich plasma. J Cosmet Dermatol. https://doi.org/10.1111/jocd.12955

66. Steller D, Herbst N, Pries R, Juhl D, Klinger M, Hakim SG (2019) Impacts of platelet-rich fibrin and platelet-rich plasma on primary osteoblast adhesion onto titanium implants in a bisphosphonate in vitro model. J Oral Pathol Med. https://doi.org/10.1111/jop. 12944

67. Moradian H, Rafiee A, Ayatollahi M (2017) Design and fabrication of a novel transplant combined with human bone marrow mesenchymal stem cells and platelet-rich fibrin: new horizons for periodontal tissue regeneration after dental trauma. Iran J Pharm Res 16(4):1370-1378

68. Elgamal A, Althani AA, Abd-Elmaksoud A, Kassab M, Farag A, Lashen S, Gabr MM, Zakaria MM, Alissawi MM, Ismail HEA, Abd El Galil A, Caceci T, Cenciarelli CC, Marei HE (2019) Xeno-free trans-differentiation of adipose tissue-derived mesenchymal stem cells into glial and neuronal cells. Am J Stem Cells 8(2): $38-51$

69. Nasirzade J, Kargarpour Z, Hasannia S, Strauss FJ, Gruber R (2019) Platelet-rich fibrin elicits an anti-inflammatory response in macrophages in vitro. J Periodontol. https://doi.org/10.1002/JPER. 19-0216

70. Liang CC, Park AY, Guan JL (2007) In vitro scratch assay: a convenient and inexpensive method for analysis of cell migration in vitro. Nat Protoc 2(2):329-333. https://doi.org/10.1038/nprot. 2007.30

71. Boyden S (1962) The chemotactic effect of mixtures of antibody and antigen on polymorphonuclear leucocytes. J Exp Med 115: 453-466. https://doi.org/10.1084/jem.115.3.453

72. Park JS, Pabst AM, Ackermann M, Moergel M, Jung J, Kasaj A (2018) Biofunctionalization of porcine-derived collagen matrix using enamel matrix derivative and platelet-rich fibrin: influence on mature endothelial cell characteristics in vitro. Clin Oral Investig 22(2):909-917. https://doi.org/10.1007/s00784-0172170-7

73. Stein GS, Lian JB (1993) Molecular mechanisms mediating proliferation/differentiation interrelationships during progressive development of the osteoblast phenotype. Endocr Rev 14(4):424 442. https://doi.org/10.1210/edrv-14-4-424

74. Chang YC, Zhao JH (2011) Effects of platelet-rich fibrin on human periodontal ligament fibroblasts and application for periodontal infrabony defects. Aust Dent J 56(4):365-371. https://doi.org/10. 1111/j.1834-7819.2011.01362.x

75. Kobayashi E, Fluckiger L, Fujioka-Kobayashi M, Sawada K, Sculean A, Schaller B, Miron RJ (2016) Comparative release of growth factors from PRP, PRF, and advanced-PRF. Clin Oral Investig 20(9):2353-2360. https://doi.org/10.1007/s00784-0161719-1

76. Miron RJ, Xu H, Chai J, Wang J, Zheng S, Feng M, Zhang X, Wei Y, Chen Y, Mourao C, Sculean A, Zhang Y (2019) Comparison of platelet-rich fibrin (PRF) produced using 3 commercially available centrifuges at both high $(\sim 700 \mathrm{~g})$ and low $(\sim 200 \mathrm{~g})$ relative centrifugation forces. Clin Oral Investig. https://doi.org/10.1007/s00784019-02981-2

77. Tsujino T, Takahashi A, Yamaguchi S, Watanabe T, Isobe K, Kitamura Y, Tanaka T, Nakata K, Kawase T (2019) Evidence for contamination of silica microparticles in advanced platelet-rich fibrin matrices prepared using silica-coated plastic tubes. Biomedicines 7(2). https://doi.org/10.3390/biomedicines7020045

78. Miron R, Choukroun J., Ghanaati, S. (2018) Controversies related to scientific report describing g-forces from studies on platelet-rich fibrin: necessity for standardization of relative centrifugal force values. International Journal of Growth Factors and Stem Cell in Dentistry

79. Pinto N, Quirynen M (2018) Letter to the editor regarding FujiokaKobayashi et al. 2017 (JOP-16-0443.R1). J Periodontol. https://doi. org/10.1002/JPER.18-0175

80. Antoniades HN, Scher CD, Stiles CD (1979) Purification of human platelet-derived growth factor. Proc Natl Acad Sci U S A 76(4): 1809-1813. https://doi.org/10.1073/pnas.76.4.1809

81. Tsukamoto T, Matsui T, Fukase M, Fujita T (1991) Platelet-derived growth factor B chain homodimer enhances chemotaxis and DNA synthesis in normal osteoblast-like cells (MC3T3-E1). Biochem Biophys Res Commun 175(3):745-751. https://doi.org/10.1016/ 0006-291x(91)91629-q

82. Noda M, Rodan GA (1986) Type-beta transforming growth factor inhibits proliferation and expression of alkaline phosphatase in murine osteoblast-like cells. Biochem Biophys Res Commun 140(1): 56-65. https://doi.org/10.1016/0006-291x(86)91057-0

83. Inagaki $Y$, Truter S, Ramirez F (1994) Transforming growth factorbeta stimulates alpha 2(I) collagen gene expression through a cisacting element that contains an Sp1-binding site. J Biol Chem 269(20):14828-14834

84. Verrecchia F, Mauviel A (2007) Transforming growth factor-beta and fibrosis. World J Gastroenterol 13(22):3056-3062. https://doi. org/10.3748/wjg.v13.i22.3056

85. Trindade R, Albrektsson T, Galli S, Prgomet Z, Tengvall P, Wennerberg A (2018) Osseointegration and foreign body reaction: titanium implants activate the immune system and suppress bone resorption during the first 4 weeks after implantation. Clin Implant Dent Relat Res 20(1):82-91. https://doi.org/10.1111/cid.12578

86. Kumar A, Mahendra J, Samuel S, Govindraj J, Loganathan T, Vashum Y, Mahendra L, Krishnamoorthy T (2019) Platelet-rich fibrin/biphasic calcium phosphate impairs osteoclast differentiation and promotes apoptosis by the intrinsic mitochondrial pathway in chronic periodontitis. J Periodontol 90(1):61-71. https://doi.org/10. 1002/JPER.17-0306

87. Castro AB, Herrero ER, Slomka V, Pinto N, Teughels W, Quirynen M (2019) Antimicrobial capacity of leucocyte-and platelet rich fibrin against periodontal pathogens. Sci Rep 9(1):8188. https://doi. org/10.1038/s41598-019-44755-6

88. Hamzacebi B, Oduncuoglu B, Alaaddinoglu EE (2015) Treatment of Peri-implant bone defects with platelet-rich fibrin. Int $\mathbf{J}$ Periodontics Restorative Dent 35(3):415-422. https://doi.org/10. 11607/prd.1861

89. Xu J, Yi J, Zhang H, Feng F, Gu S, Weng L, Zhang J, Chen Y, An N, Liu Z, An Q, Yin W, Hu X (2018) Platelets directly regulate DNA 
damage and division of Staphylococcus aureus. FASEB J 32(7): 3707-3716. https://doi.org/10.1096/fj.201701190R
Publisher's note Springer Nature remains neutral with regard to jurisdictional claims in published maps and institutional affiliations. 